International Journal of Software Engineering \& Applications (IJSEA), Vol.7, No.3, May 2016

\title{
A COMPARISON STUdY OF ESTIMATION METHODS FOR GENERALIZED JELINSKI-MORANDA MODEL BASED ON VARIOUS SIMULATED PATTERNS
}

\author{
Lutfiah Ismail Al turk ${ }^{1}$ and Eftekhar Gabel Alsolami ${ }^{2}$ \\ ${ }^{1}$ Statistics Department, King Abdulaziz University, Kingdom of Saudi Arabia \\ lturk@kau.edu.sa \\ ${ }^{2}$ Mathematics Department, University of Jeddah, Kingdom of Saudi Arabia \\ ekalsulami@uj.edu.sa
}

ABSTRACT

In this paper three methods for estimating the parameters of the generalized Jelinski-Moranda (GJM) model are compared. The needed mathematical formulas for resolving the estimates are derived. Because of the lack of various real data with changed input data size different simulation scenarios are given to help achieving our goals. Illustrative algorithms for the simulation studies are given. First, the accuracy of the GJ-M model's estimators is checked based on two evaluation criteria. Moreover, several generated models from the GJ-M general formula are evaluated based on three different methods of comparison. Useful results for the software reliability modelling area are concluded.

\section{KEYWORDS}

Generalized Jelinski-Moranda (GJM) model, Simulations, Maximum likelihood estimation, Nonlinear least squares estimation, Weighted nonlinear least squares estimation.

\section{INTRODUCTION}

The main interest of many costumers and developers is software reliability. Software reliability model is a mathematical formula that describes the software failure process as a function of factors, failure time and one of reliability measures. In fact, statistical modeling for quantifying software reliability is a useful approach but before using this approach careful attention should be paid to select the appropriate model that can best quantify and predict reliability. Selecting inappropriate model can be considered as one of this approach limitations. In the other hand, studying several models with different failure rate behavior among the huge numbers of proposed reliability models during the last 45 years could help to avoid this limitation. The classical Jelinski- Moranda (J-M) model [ Jelinski and Moranda (1972)] is one of the most elementary models, and it forms the basis of further software reliability models either as a modifications or as an extensions. This model assumes that the failure rate is proportional to the number of remaining faults and each fault contributes the same to the failure rate.The generalized Jelinski-Moranda (GJM) model [Al turk and Alsolami (2016)] which also assumes that fault detection and correction begins when a program contains $\mathrm{N}$ faults and all the faults have the same rate $\varphi$ could 
offer several reliability sub-models with various failure rate behaviour based on its shape parameter $\beta$. Those generated sub-models could be checked for a given system with less effort and time, the $\mathrm{J}-\mathrm{M}$ model is a special case of this general model when $\beta=1$. The purpose of this paper is to study the accuracy of the GJ-M model's three estimators using the maximum likelihood (ML), nonlinear least squares (NLS), weighted nonlinear least squares (WNLS) estimation methods. Another purpose is to compare several generated models as special cases from the GJ-M model based also on those three chosen estimation methods. Two studies based on several simulated Pattern are conducted to achieve our purposes. Generating various simulated patterns will help us to study various situations that could not be offered by the limited available real data sets. Moreover, simulating different size of failure time data will help to investigate the changing in the input data size.

The rest of this paper is arranged as follows: Section 2 describes the MLE, NLSE, and WNLSE approaches for the GJ-M model. Section 3 illustrates the evaluation criteria that will be used in our evaluation. Simulation studies will be discussed in Sections 4. In the end, Section 5 is the conclusion of this paper.

\section{PARAMETER ESTIMATION OF THE GENERLIZED JELINSKI-MORANDA (GJ-M) MODEL}

The GJ-M model which is suggested By Al turk and Alsolami in (2016) assumes that the amount of debugging time between fault occurrences has a Weibull distribution. The faults rate is proportional to the number of faults remaining multiplying by the term $\eta \mathrm{t}_{\mathrm{i}}^{\eta-1}$, and each fault discovered is immediately removed thus reducing the number of faults by one. According to these assumptions, the probability density function (pdf) of the GJ-M is defined as follows:

$f\left(t_{i}\right)=\varphi[N-(i-1)] \beta t_{i}^{\beta-1} e^{-\varphi[N-(i-1)] t_{i}^{\beta}}$

Where

$\mathrm{i}:$ is the fault index.

$\varphi:$ is a proportionality constant.

$\mathrm{N}$ : is the number of initial faults present in system.

$\beta:$ is the shape parameter.

$\mathrm{t}_{\mathrm{i}}$ : is the $\mathrm{i}^{\text {th }}$ time interval between detection of $(\mathrm{i}-1)^{\text {st }}$ and $\mathrm{i}^{\text {th }}$ faults.

The reliability of this model can be obtained as follows:

$\mathrm{R}\left(\mathrm{t}_{\mathrm{i}}\right)=\mathrm{e}^{-\varphi[\mathrm{N}-(\mathrm{i}-1)] \mathrm{t}_{\mathrm{i}}^{\beta}}$

Additionally, the mean time to failure can be represented by expression:

$$
\mathrm{E}\left(\mathrm{t}_{\mathrm{i}}\right)=\operatorname{MTTF}\left(\mathrm{t}_{\mathrm{i}}\right)
$$




$$
=\frac{1}{\beta}\{\varphi[\mathrm{N}-(\mathrm{i}-1)]\}^{-\frac{1}{\beta}} \Gamma\left(\frac{1}{\beta}\right)
$$

While, the variance is given by:

$$
\begin{aligned}
\operatorname{var}\left(\mathrm{t}_{\mathrm{i}}\right) & =\mathrm{E}\left(\mathrm{t}_{\mathrm{i}}{ }^{2}\right)-\left(\mathrm{E}\left(\mathrm{t}_{\mathrm{i}}\right)\right)^{2} \\
& =\frac{\Gamma\left(\frac{2}{\beta}+1\right)}{[\varphi(\mathrm{N}-(\mathrm{i}-1))]^{\frac{2}{\beta}}}-\frac{\Gamma^{2}\left(\frac{1}{\beta}+1\right)}{[\varphi(\mathrm{N}-(\mathrm{i}-1))]^{\frac{2}{\beta}}} \\
& =\frac{\Gamma\left(\frac{2}{\beta}+1\right)-\Gamma^{2}\left(\frac{1}{\beta}+1\right)}{[\varphi(\mathrm{N}-(\mathrm{i}-1))]^{\frac{2}{\beta}}} \\
& =\frac{\Gamma\left(\frac{2}{\beta}+1\right)-\Gamma^{2}\left(\frac{1}{\beta}+1\right)}{[\varphi(\mathrm{N}-(\mathrm{i}-1))]^{\frac{2}{\beta}}}
\end{aligned}
$$

More details and measures of reliability for the GJM model can be found in [Al turk and Alsolami (2016)]

\subsection{Maximum Likelihood Estimation (MLE) Method}

Parameter estimation is of primary importance in software reliability prediction. The maximum likelihood estimation (MLE) method is the most important traditional and widely used estimation technique. This technique has several properties including consistency, efficiency and asymptotic normality. For the purpose of estimating the unknown three parameters $N, \varphi$, and $\beta$ of the GJM model using MLE method and based on the failure time data set $\left\{\mathrm{t}_{1}, \mathrm{t}_{2}, \ldots, \mathrm{t}_{\mathrm{n}} ; \mathrm{n}>0\right\}$, the likelihood function will be defined as follows:

$\mathrm{L}(\mathrm{N}, \varphi, \beta)=\beta^{\mathrm{n}} \varphi^{\mathrm{n}} \prod_{\mathrm{i}=1}^{\mathrm{n}}[\mathrm{N}-(\mathrm{i}-1)] \mathrm{t}_{\mathrm{i}}^{\beta-1} \mathrm{e}^{-\varphi \sum[\mathrm{N}-(\mathrm{i}-1)] \mathrm{t}_{\mathrm{i}}^{\beta}}$

To simplify the computation, the natural logarithm of both sides will be taken as follows:

$$
\begin{aligned}
\ln L(N, \varphi, \beta) & =\operatorname{nln}(\eta)+\operatorname{nln}(\varphi)+\sum_{i=1}^{n} \ln [N-(i-1)]+\beta \sum_{i=1}^{n} \ln t_{i} \\
& -\sum_{i=1}^{n} \ln t_{i}-\varphi \sum_{i=1}^{n}[N-(i-1)] t_{i}{ }^{\beta}
\end{aligned}
$$

By taking the first partial derivative of Equation (6) with respect to $\varphi, \mathrm{N}$ and $\beta$, we obtain:

$$
\frac{\partial \mathrm{L}(\mathrm{N}, \varphi, \beta)}{\partial \varphi}=\frac{\mathrm{n}}{\varphi}-\sum_{\mathrm{i}=1}^{\mathrm{n}}[\mathrm{N}-(\mathrm{i}-1)] \mathrm{t}_{\mathrm{i}}^{\beta}
$$


International Journal of Software Engineering \& Applications (IJSEA), Vol.7, No.3, May 2016

$$
\begin{gathered}
\frac{\partial \mathrm{L}(\mathrm{N}, \varphi, \beta)}{\partial \mathrm{N}}=\sum_{\mathrm{i}=1}^{\mathrm{n}} \frac{1}{[\mathrm{~N}-(\mathrm{i}-1)]}-\varphi \sum_{\mathrm{i}=1}^{\mathrm{n}} \mathrm{t}_{\mathrm{i}}{ }^{\beta} \\
\frac{\partial \mathrm{L}(\mathrm{N}, \varphi, \beta)}{\partial \beta}=\frac{\mathrm{n}}{\beta}+\sum_{\mathrm{i}=1}^{\mathrm{n}} \ln \mathrm{t}_{\mathrm{i}}-\varphi \sum_{\mathrm{i}=1}^{\mathrm{n}}[\mathrm{N}-(\mathrm{i}-1)] \mathrm{t}_{\mathrm{i}}{ }^{\beta} \operatorname{lnt}_{\mathrm{i}}
\end{gathered}
$$

Then by setting $\frac{\partial \mathrm{L}(\mathrm{N}, \varphi, \beta)}{\partial \varphi}=0, \frac{\partial \mathrm{L}(\mathrm{N}, \varphi, \beta)}{\partial \mathrm{N}}=0$, and $\frac{\partial \mathrm{L}(\mathrm{N}, \varphi, \beta)}{\partial \beta}=0$, the ML estimates of the GJ-M model's three parameters should satisfy the following equations:

$\widehat{\varphi}=\frac{\mathrm{n}}{\sum_{\mathrm{i}=1}^{\mathrm{n}}[\mathrm{N}-(\mathrm{i}-1)] \mathrm{t}_{\mathrm{i}}{ }^{\beta}}$

$\frac{\mathrm{n} \sum_{\mathrm{i}=1}^{\mathrm{n}} \mathrm{t}_{\mathrm{i}}{ }^{\beta}}{\sum_{\mathrm{i}=1}^{\mathrm{n}}[\mathrm{N}-(\mathrm{i}-1)] \mathrm{t}_{\mathrm{i}}^{\beta}}=\sum_{\mathrm{i}=1}^{\mathrm{n}} \frac{1}{[\mathrm{~N}-(\mathrm{i}-1)]}$

$\frac{\mathrm{n}}{\beta}+\sum_{\mathrm{i}=1}^{\mathrm{n}} \operatorname{lnt} \mathrm{t}_{\mathrm{i}}=\frac{\mathrm{n} \sum_{\mathrm{i}=1}^{\mathrm{n}}(\mathrm{N}-(\mathrm{i}-1)) \mathrm{t}_{\mathrm{i}}{ }^{\beta} \operatorname{lnt} \mathrm{t}_{\mathrm{i}}}{\sum_{\mathrm{i}=1}^{\mathrm{n}}[\mathrm{N}-(\mathrm{i}-1)] \mathrm{t}_{\mathrm{i}}{ }^{\beta}}$

\subsection{Nonlinear Least Squares Estimation (NLSE) Method}

The nonlinear least squares NLS estimates are obtained by minimizing the following objective function:

$\psi_{\mathrm{NLS}}(\mathrm{N}, \varphi, \beta)=\sum_{\mathrm{i}=1}^{\mathrm{n}}\left[\mathrm{t}_{\mathrm{i}}-\frac{\Gamma\left(\frac{1}{\beta}+1\right)}{[\varphi(\mathrm{N}-\mathrm{i}+1)]^{\frac{1}{\beta}}}\right]^{2}$

Taking the first partial derivative of Equation (10), which assumes that each observation has an equal weight, with respect to $\varphi$ and $\mathrm{N}$, and $\beta$ and equate the obtained equations to zero $\left[\frac{\partial \Psi_{\mathrm{NLS}}(\mathrm{N}, \varphi, \beta)}{\partial \varphi}=0, \frac{\partial \psi \psi_{\mathrm{NLS}}(\mathrm{N}, \varphi, \beta)}{\partial \mathrm{N}}=0, \frac{\partial \Psi_{\mathrm{NLS}}(\mathrm{N}, \varphi, \beta)}{\partial \beta}=0\right]$ we obtain:

$\widehat{\varphi}=\left[\Gamma\left(\frac{1}{\beta}+1\right) \sum_{\mathrm{i}=1}^{\mathrm{n}} \frac{1}{[(\mathrm{~N}-\mathrm{i}+1)]^{\frac{2}{\beta}}} / \sum_{\mathrm{i}=1}^{\mathrm{n}} \frac{\mathrm{t}_{\mathrm{i}}}{[(\mathrm{N}-\mathrm{i}+1)]^{\frac{1}{\beta}}}\right]^{\beta}$

$\sum_{i=1}^{n} \frac{t_{i}}{(N-i+1)^{\frac{1}{\beta}+1}}=\frac{\Gamma\left(\frac{1}{\beta}+1\right)}{\widehat{\varphi}^{\frac{1}{\beta}}} \sum_{i=1}^{n} \frac{1}{(N-i+1)^{\frac{2}{\beta}+1}}$

$$
\begin{aligned}
\Gamma^{\prime}\left(\frac{1}{\beta}+1\right)\left\{\sum_{\mathrm{i}=1}^{\mathrm{n}} \frac{\mathrm{t}_{\mathrm{i}}}{(\mathrm{N}-\mathrm{i}+1)^{\frac{1}{\beta}}}-\frac{\Gamma\left(\frac{1}{\beta}+1\right)}{\hat{\varphi}^{\frac{1}{\beta}}} \sum_{\mathrm{i}=1}^{\mathrm{n}} \frac{1}{(\mathrm{~N}-\mathrm{i}+1)^{\frac{2}{\beta}}}\right\}= \\
\quad \frac{\Gamma\left(\frac{1}{\beta}+1\right)}{\beta^{2}}\left\{\sum_{\mathrm{i}=1}^{\mathrm{n}} \frac{\mathrm{t}_{\mathrm{i}}[\ln \hat{\varphi}+\ln (\mathrm{N}-\mathrm{i}+1)]}{(\mathrm{N}-\mathrm{i}+1)^{\frac{1}{\beta}}}-\frac{\Gamma\left(\frac{1}{\beta}+1\right)}{\hat{\varphi}^{\frac{1}{\beta}}} \sum_{\mathrm{i}=1}^{\mathrm{n}} \frac{[\ln \hat{\varphi}+\ln (\mathrm{N}-\mathrm{i}+1)]}{(\mathrm{N}-\mathrm{i}+1)^{\frac{2}{\beta}}}\right\}
\end{aligned}
$$


Where $\Gamma^{\prime}(\mathrm{z})=\int_{0}^{\infty} \mathrm{dt}(\ln \mathrm{t}) \mathrm{t}^{\mathrm{z}-1} \mathrm{e}^{-\mathrm{t}}$

The NLS estimates of $N$ and $\beta$ can be obtained by solving the Equations (12 and 13). Then by substituting the obtained estimated values of $N$ and $\beta$ into Equation (11), we get the NLS estimate of $\varphi$.

\subsection{Weighted Nonlinear Least Squares Estimation (WNLSE) Method}

As seen from Equation (4), the variance of the GJ-M model varies with the inter-failure time data, accordingly using the WNLSE method may give more accurate estimates of the model's parameters. The WNLS estimates will be obtained by minimizing the following objective function:

$\psi_{\mathrm{WNLS}}(\mathrm{N}, \varphi, \beta)=\sum_{\mathrm{i}=1}^{\mathrm{n}} \mathrm{W}_{\mathrm{i}}\left[\mathrm{t}_{\mathrm{i}}-\frac{\Gamma\left(\frac{1}{\beta}+1\right)}{[\varphi(\mathrm{N}-\mathrm{i}+1)]^{\frac{1}{\beta}}}\right]^{2}$

Taking the first partial derivative of the above function with respect to $\varphi, \mathrm{N}$ and $\beta$, and equate the obtained equations to zero, we obtain Equations (15, 16 and 17):

$$
\begin{aligned}
& \frac{\partial \Psi_{\mathrm{WNLS}}(\mathrm{N}, \varphi, \beta)}{\partial \varphi}=0 \\
& \widehat{\varphi}=\left[\Gamma\left(\frac{1}{\beta}+1\right) \sum_{\mathrm{i}=1}^{\mathrm{n}} \frac{\mathrm{w}_{\mathrm{i}}}{[(\mathrm{N}-\mathrm{i}+1)]^{\frac{2}{\beta}}} / \sum_{\mathrm{i}=1}^{\mathrm{n}} \frac{\mathrm{w}_{\mathrm{i}} \mathrm{t}_{\mathrm{i}}}{[(\mathrm{N}-\mathrm{i}+1)]^{\frac{1}{\beta}}}\right]^{\beta} \\
& \frac{\partial \psi_{\mathrm{WNLS}}(\mathrm{N}, \varphi, \beta)}{\partial \mathrm{N}}=0 \\
& \sum_{\mathrm{i}=1}^{\mathrm{n}} \frac{\mathrm{w}_{\mathrm{i}} \mathrm{t}_{\mathrm{i}}}{(\mathrm{N}-\mathrm{i}+1)^{\frac{1}{\beta^{3}}}}=\frac{\Gamma\left(\frac{1}{\beta}+1\right)}{\widehat{\varphi}^{\frac{1}{\beta}}} \sum_{\mathrm{i}=1}^{\mathrm{n}} \frac{\mathrm{w}_{\mathrm{i}}}{(\mathrm{N}-\mathrm{i}+1)^{\frac{2}{\beta^{+}+1}}} \\
& \frac{\partial \psi_{\mathrm{WNLS}}(\mathrm{N}, \varphi, \beta)}{\partial \beta}=0 \\
& \Gamma^{\prime}\left(\frac{1}{\beta}+1\right)\left\{\sum_{\mathrm{i}=1}^{\mathrm{n}} \frac{\mathrm{w}_{\mathrm{i}} \mathrm{t}_{\mathrm{i}}}{(\mathrm{N}-\mathrm{i}+1)^{\frac{1}{\beta}}}-\frac{\Gamma\left(\frac{1}{\beta}+1\right)}{\widehat{\varphi}^{\frac{1}{\beta}}} \sum_{\mathrm{i}=1}^{\mathrm{n}} \frac{\mathrm{w}_{\mathrm{i}}}{(\mathrm{N}-\mathrm{i}+1)^{\frac{2}{\beta}}}\right\}=
\end{aligned}
$$


$\frac{\Gamma\left(\frac{1}{\beta}+1\right)}{\beta^{2}}\left\{\sum_{\mathrm{i}=1}^{\mathrm{n}} \frac{\mathrm{w}_{\mathrm{i}} \mathrm{t}_{\mathrm{i}}[\ln \widehat{\varphi}+\ln (\mathrm{N}-\mathrm{i}+1)]}{(\mathrm{N}-\mathrm{i}+1)^{\frac{1}{\beta}}}-\frac{\Gamma\left(\frac{1}{\beta}+1\right)}{\hat{\varphi}^{\frac{1}{\beta}}} \sum_{\mathrm{i}=1}^{\mathrm{n}} \frac{\mathrm{w}_{\mathrm{i}}[\ln \widehat{\varphi}+\ln (\mathrm{N}-\mathrm{i}+1)]}{(\mathrm{N}-\mathrm{i}+1)^{\frac{2}{\beta}}}\right\}$

Where $\Gamma^{\prime}(\mathrm{z})=\int_{0}^{\infty} \mathrm{dt}(\ln \mathrm{t}) \mathrm{t}^{\mathrm{z}-1} \mathrm{e}^{-\mathrm{t}}$

By solving the Equations (16 and 17) using Gauss-Newton method $\widehat{\mathrm{N}}$ and $\widehat{\beta}$ can be obtained, then $\widehat{\varphi}$ can be found by substituting $\widehat{N}$ and $\widehat{\beta}$ in Equation (15).

\section{EVALUATION CRITERIA}

The mean of square errors (MSE), the root mean of square errors (RMSE), the mean absolute errors (MAE) and the mean absolute percentage error (MAPE) criteria are used for the evaluation purpose in our simulation studies. The lower the criteria value, the better performance we get. The formulas of those criteria are shown in Table (1).

Table 1: Some evaluation criteria.

\begin{tabular}{l|c}
\hline \multicolumn{1}{c|}{ Criteria Name } & Criteria formula \\
\hline \hline MSE & $\frac{1}{\mathrm{n}-\mathrm{k}} \sum_{\mathrm{i}=1}^{\mathrm{n}}\left(\mathrm{y}_{\mathrm{i}}-\hat{\mathrm{y}}_{\mathrm{i}}\right)^{2}$ \\
\hline [Zhanget al. (2003)]. & $\frac{\sum_{\mathrm{i}=1}^{\mathrm{n}}\left(\frac{\left|\mathrm{y}_{\mathrm{i}}-\hat{\mathrm{y}}_{\mathrm{i}}\right|}{\mathrm{y}_{\mathrm{i}}}\right)}{\mathrm{n}} \times 100 \%$ \\
\hline [Gentry et al. (1995)] & $\sqrt{\frac{1}{\mathrm{n}-\mathrm{k}} \sum_{\mathrm{i}=1}^{\mathrm{n}}\left[\mathrm{y}_{\mathrm{i}}-\hat{\mathrm{y}}_{\mathrm{i}}\right]^{2}}$ \\
\hline RMSE & $\frac{1}{\mathrm{n}-\mathrm{k}} \sum_{\mathrm{i}=1}^{\mathrm{n}}\left|\mathrm{y}_{\mathrm{i}}-\hat{\mathrm{y}}_{\mathrm{i}}\right|$ \\
[Chai and Draxler (2014)]. & \\
\hline MAE & \\
[Chai and Draxler (2014)]. & \\
\hline $\begin{array}{l}\text { Where }: \text { is thefault index. } \\
\hat{y}_{\mathrm{i}}: \text { is the predicted value. } \\
\mathrm{y}_{\mathrm{i}} \text { :is the true value. } \\
\text { n: the sample size of the data } \\
\mathrm{k}: \text { the number of parameters. }\end{array}$ \\
\hline
\end{tabular}




\section{SIMULATION STUDY}

Simulation study was conducted to assess the performance of the GJ-M model under different simulated patterns of software systems. A wide variety of situations were generated by setting different values of the GJ-M model's three parameters and various sample sizes. In fact, our simulation is designed for two motivations: first to compare the precision of the estimators; then to assess the performance of the different generated submodels of the GJ-M model, particularly, to focus on their performance for predicting software reliability.

\subsection{Simulation algorithms}

Two simulation algorithms has been designed and coded in $\mathrm{R}$ programming language version 3.2.3 to help achieving our motivations:

\section{Algorithm 1: For Part I}

Step 1: Generate 15, 30, 50, and 100 independent uniform $U(0,1)$ random variables.

Step 2: For each sample size and using the following equation:

$\mathrm{t}_{\mathrm{i}}=(\ln (\mathrm{u}) / \varphi[\mathrm{N}-(\mathrm{i}-1)])^{\frac{1}{\beta}}$, the following four simulation scenarios will be generated:

- $\varphi=0.5, \mathrm{~N}=150$, and $\beta=0.5,1,2$.

- $\varphi=0.5, \mathrm{~N}=250$, and $\beta=0.5,1,2$.

- $\varphi=1.5, \mathrm{~N}=150$, and $\beta=0.5,1,2$.

- $\varphi=1.5, \mathrm{~N}=250$, and $\beta=0.5,1,2$.

Step 3: Define initial values of the model's parameters and use Equation (6) and package nlminb to obtain the maximum likelihood (ML) estimates of parameters.

Step 4: Define initial values of the model's parameters and use Equation (10) and package minpack.lm to obtain nonlinear least square (NLS) estimates of parameters.

Step 5: Define initial values of the model's parameters, set $\mathrm{w}_{\mathrm{i}}=1 / \mathrm{i}$ where $\mathrm{i}=1,2, \ldots, \mathrm{n}$ and use Equation (14) and package minpack.lm to obtain the weighted nonlinear least squares (WNLS) estimates of parameters.

Step 6: Use the MSE and MAPE formulas in Table (1) to check the accuracy of (ML, NLS, and WNLS) estimates.

Step 7: For each sample size in Step 1, (Step 1 to 6) will be repeated a large number of times (5000 times in our simulation study) and the average of the parameters estimates and assessment criteria will be computed.

\section{Algorithm 2: For Part II}

Step 1: Generate 100 independent uniform U $(0,1)$ random variables.

Step 2: Generate three simulated data sets with the following assumptions:

- $\varphi=0.01, \mathrm{~N}=150$ and $\beta=3.5$

- $\varphi=0.01, \mathrm{~N}=150, \beta=5$

- $\varphi=0.01, \mathrm{~N}=150, \beta=8.5$, and using the following equation: 
International Journal of Software Engineering \& Applications (IJSEA), Vol.7, No.3, May 2016

$$
\mathrm{t}_{\mathrm{i}}=(\ln (\mathrm{u}) / \varphi[\mathrm{N}-(\mathrm{i}-1)])^{\frac{1}{\beta}}
$$

Step 3: Set $[\varphi=0.01, N=150$, and $\beta=0.5,1,1.5,2,2.5$, and 3] to generate six sub-models as special cases of the GJ-M model.

Step 4: Estimate the generated models' parameters based on MLE, NLSE, and NWLSE estimation methods, to accomplish this step values of the model's parameters are initialized, set $\mathrm{w}_{\mathrm{i}}=1 / \mathrm{i}$ where $\mathrm{i}=1,2, \ldots, \mathrm{n}$, Equation $(6,10$, and 14$)$ will be used, and nlminb and minpack.lm packages will be utilized.

Step 5: Select the best fit model among the six generated models based on three selection methods MSE, RMSE, and AME using their mathematical formulas in Table (1).

\subsection{Simulation results and discussion}

The results of the simulation experiments are summarized in Tables (2, 3, 4, and 5), and will be discussed in this section.

\section{Part I: Studying and comparing the accuracy of the ML, NLS, WNLS estimates}

Table (2) demonstrates the average values of the parameter estimates for the MLE, NLSE, and WNLSE methods along with their average MSE and MAPE over the 5000 simulations, under four simulated situations: $[\varphi=0.5, \mathrm{~N}=150, \beta=0.5,1,2],[\varphi=1.5, \mathrm{~N}=150, \beta=0.5,1,2]$, $[\varphi=0.5, \mathrm{~N}=250, \beta=0.5,1,2]$, and $[\varphi=1.5, \mathrm{~N}=250, \beta=0.5,1,2]$ with considering different sample sizes [n $=15,30,50$, and 100]. Each sub-table includes 12 comparison cases for each of the three parameters.

In Table (2.a): 4 cases illustrate that the NLS estimates for the parameter $\varphi$ perform the best and are the closer to the true values, while 8 cases illustrate that the WNLSE method give the best estimates values, none of the cases are for the sake of the MLE method. For the parameter N, 8 cases are for the sake of the NLS method, 5 cases are for the sake of WNLS, and again none of the cases are for the sake of MLE methods. Regarding to the parameter $\beta$, the NLSE and WNLSE perform the same with approximately zero values of the average of the two evaluation criteria while the MLE method has larger average values of the MSE and MAPE criteria Moreover, it obvious that the average values of MSE and MAPE values in this table decreases as the sample sizes increases.

For the simulated scenario in Table (2.b) we assumed the parameter $\varphi$ which represents the contribution by each failure in failure intensity to be greater than 1, for this scenario the NLSE and WNLSE methods behave the same with a slight difference for the sake of WNLSE method and again the MLE method takes the third rank. For the parameter $\mathrm{N}$ the best performance is from the NLSE method while the WNLS and the MLE methods take the second and third rank respectively and also there is no noticeably difference between the obtained results from the NLSE and WNLSE methods. Lastly, the average values of the MSE and MAPE for $\beta$ seems to be comparatively the same for NLSE and WNLSE methods and smaller than the MLE method. With respect to assuming larger $\varphi$ value in this pattern, this assumption gives smaller criteria values for 
the estimates of the three parameters in most of the cases. Also, it is noticeable that the criteria values decreases as the sample sizes increases.

While for on the simulation situation in Table (2.c),which assumed larger number of initial faults present in system, the overall results show that the average values of the two evaluation criteria tends to be the smallest for the NLSE method when estimating the parameters $\varphi$ and N, and tends to be the same with WNLSE when estimating the parameter $\beta$. The MLE method has the larger values of the average evaluation criteria for all cases. Moreover, assuming larger $\mathrm{N}$ value in this pattern gives larger average values of the MSE and MAPE criteria. Also, if the sample size is increased, the values of evaluation criteria are lower.

For the simulated pattern in Table (2.d) it is again as the results above, the NLS estimator seems to perform better than the WNLS and ML estimators with respect to the average values of the MSE and MAPE criteria for the parameters $\varphi$ and $N$ with a minor difference in the results of the NLSE and WNLSE methods, but for the parameter $\beta$ the NLSE and WNLS behavethe same as they have smaller MSE and MAPE than the MLE method, also for in this pattern by increasing the sample size lower criteria values are obtained. According to the results in this part some concluding points could be summarized as follows:

- The overall results show that the average values of MSE and MAPE tends to get smaller when the sample sizes increases so the larger the sample size the more information about the failure process and more reliable results we have and this indicates the need for big software reliability real data to make reliable release decisions.

- The NLSE and WNLSE methods give more consistent estimate values than the MLE method for all the three GJ-M model's parameters under all our simulated patterns.

- The results indicate that there is no major difference between the accuracy of the NLSE and WNLSE methods, their average values of MSE and MAPE either close or the same in most of our considered cases.

- Assuming larger value of the failure rate contributed by each fault gives smaller average values of MSE and MAPE in most of the selected cases. Maybe this indicates that removing faults with larger contribution will give more enhancements to the accuracy of the obtained estimates.

- Assuming larger value of initial faults present in system gives larger average values of MSE and MAPE in all the studied cases. Maybe this indicates that having greater start number of faults in a given system will negatively affect the accuracy of its obtained estimates.

Part II: Investigate the performance of some of the sub-models as special cases of the GJ-M model

Tables (2, 3, and 4)present results of simulation numerical experiments to compare the performance of the six special cases of the GJ-M model. The six sub-models were generated by assuming: $[\varphi=0.5, \mathrm{~N}=150, \beta=0.5,1,1.5,2,2.5$, and 3]. For this comparison three data sets were simulated by assuming $\varphi=0.5, \mathrm{~N}=150$ and the following assumptions for the shape parameter for each data set: Data 1: $\beta=3.5$, Data 2: $\beta=5.5$, and Data 3: $\beta=8$. The estimates were found by using the MLE, NLSE, and WNLSE methods. The performance of the models was 
evaluated based on the MSE, RMSE, andAME criteria. According to the results in Tables $(3,4$, and 5) the following points are concluded:

- According to our study, The ML estimates are unstable as they have big values of the evaluation criteria compared to the true values while the NLE and WNLSE methods give more accurate estimates.

- In most of the cases, the best performance is obtained when using the WNLSE methods.

- Model 6 is the best fit model for simulated Data (1,2, and 3) using the three estimation methods and based on to the MSE, RMSE, and AME criteria.

Table 2: The average values of ML, NLS, andWNLS estimates along with average MSE and MAPE ofeach special case of the GJ-M Modelfrom 5000 simulations of sample sizes $\mathrm{n}=$ $(15,30,50,100)$.

Table (2.a): Scenario $1 ;[\varphi=0.5, N=150$, and $\beta=0.5,1,2]$.

Bold numbers indicates the best estimates accuracy.

\begin{tabular}{|c|c|c|c|c|c|c|}
\hline \multirow{3}{*}{$\begin{array}{l}\text { Method of } \\
\text { estimation }\end{array}$} & \multicolumn{6}{|c|}{$\begin{array}{c}\text { Repetition }=5000 \\
\text { True parameters: } \varphi=0.5, N=150, \text { and } \beta=0.5,1,2 .\end{array}$} \\
\hline & \multicolumn{3}{|c|}{$\mathrm{v}=15$} & \multicolumn{3}{|c|}{$\mathrm{n}=30$} \\
\hline & $\begin{array}{l}\stackrel{\hat{\rho}}{\left(\mathrm{MSE}_{\phi}\right)} \\
\left(\mathrm{MAPE}_{\phi} \%\right)\end{array}$ & $\begin{array}{c}\bar{N} \\
\left(\operatorname{MSE}_{N_{0}}\right) \\
\left(\operatorname{MAPE}_{N_{0}} \%\right)\end{array}$ & $\begin{array}{c}\widehat{\widehat{B}} \\
\left(\mathrm{MSE}_{p}\right) \\
\left(\mathrm{MAPE}_{\bar{p}} \%\right)\end{array}$ & $\begin{array}{c}\stackrel{\oplus}{\oplus} \\
\left(\mathrm{MSE}_{\phi}\right) \\
\left(\mathrm{MAPE}_{q} \%\right)\end{array}$ & $\begin{array}{c}N \\
\left(\operatorname{MSE}_{\boldsymbol{N}_{\varepsilon_{0}}}\right) \\
\left(\operatorname{MAPE}_{N_{0}} \%\right)\end{array}$ & $\begin{array}{c}\overline{\bar{B}} \\
\left(\mathrm{MSE}_{\mathrm{p}}\right) \\
\left(\mathrm{MAPE}_{\mathrm{g}} \%\right)\end{array}$ \\
\hline \multirow{3}{*}{ MIE } & $\begin{array}{c}4.89 \mathrm{e}-01 \\
(2.13 \mathrm{e}-04) \\
(3.69 \mathrm{e}-01)\end{array}$ & $\begin{array}{c}1.44 \mathrm{e}+02 \\
(2.27 \mathrm{e}+01) \\
(2.63 \mathrm{e}-01)\end{array}$ & $\begin{array}{c}4.58 \mathrm{e}-01 \\
(2.22 \mathrm{e}-04) \\
(5.88 \mathrm{e}-01)\end{array}$ & $\begin{array}{c}4.96 \mathrm{e}-01 \\
(5.57 \mathrm{e}-0.5) \\
(1.40 \mathrm{e}-01)\end{array}$ & $\begin{array}{c}1.45 \mathrm{e}+02 \\
(0.64 \mathrm{e}+01) \\
(1.03 \mathrm{e}-01)\end{array}$ & $\begin{array}{c}4.63 e-01 \\
(7.37 e-05) \\
(2.54 e-01)\end{array}$ \\
\hline & $\begin{array}{c}4.69 \mathrm{e}-01 \\
(3.37 \mathrm{e}-04) \\
(5.74 \mathrm{e}-01)\end{array}$ & $\begin{array}{c}1.39 \mathrm{e}+02 \\
(3.67 \mathrm{e}+01) \\
(5.00 \mathrm{e}-01)\end{array}$ & $\begin{array}{c}9.82 \mathrm{e}-01 \\
(2.10 \mathrm{e}-04) \\
(2.05 \mathrm{e}-01)\end{array}$ & $\begin{array}{c}4.77 \mathrm{e}-01 \\
(1.02 \mathrm{e}-04) \\
(2.33 \mathrm{e}-01)\end{array}$ & $\begin{array}{c}1.41 e+02 \\
(1.09 e+01) \\
(2.07 e-01)\end{array}$ & $\begin{array}{c}9.94 e-01 \\
(3.99 e-05) \\
(6.69 e-02)\end{array}$ \\
\hline & $\begin{array}{c}4.83 e-01 \\
(2.37 \mathrm{e}-04) \\
(4.25 \mathrm{e}-01)\end{array}$ & $\begin{array}{c}1.42 \mathrm{e}+02 \\
(2.80 \mathrm{e}+01) \\
(3.64 \mathrm{e}-01)\end{array}$ & $\begin{array}{c}0.19 \mathrm{e}+01 \\
(1.77 \mathrm{e}-03) \\
(3.37 \mathrm{e}-01)\end{array}$ & $\begin{array}{c}4.91 \mathrm{e}-01 \\
(6.37 \mathrm{e}-05) \\
(1.60 \mathrm{e}-01)\end{array}$ & $\begin{array}{c}1.44 e+02 \\
(0.73 e+01) \\
(1.33 e-01)\end{array}$ & $\begin{array}{c}0.19 e+01 \\
(4.56 e-04) \\
(1.24 e-01)\end{array}$ \\
\hline \multirow{3}{*}{ NLSE } & $\begin{array}{c}5.01 \mathrm{e}-01 \\
(7.79 \mathrm{e}-07) \\
(1.59 \mathrm{e}-02)\end{array}$ & $\begin{array}{c}1.49 \mathrm{e}+02 \\
(7.50 \mathrm{e}-02) \\
(1.62 \mathrm{e}-02)\end{array}$ & $\begin{array}{c}495 \mathrm{e}-01 \\
(0) \\
(0)\end{array}$ & $\begin{array}{c}5.00 \mathrm{e}-01 \\
(5.20 \mathrm{e}-08) \\
(1.26 \mathrm{e}-03)\end{array}$ & $\begin{array}{c}1.49 \mathrm{e}+02 \\
(4.98 \mathrm{e}-03) \\
(1.25 \mathrm{e}-03)\end{array}$ & $\begin{array}{c}495 e-01 \\
(0) \\
(0)\end{array}$ \\
\hline & $\begin{array}{c}5.01 \mathrm{e}-01 \\
(4.89 \mathrm{e}-07) \\
(1.02 \mathrm{e}-02)\end{array}$ & $\begin{array}{c}1.49 \mathrm{e}=02 \\
(3.53 \mathrm{e}-02) \\
(9.12 \mathrm{e}-03)\end{array}$ & $\begin{array}{c}0.10 \mathrm{e}=01 \\
(0) \\
(0)\end{array}$ & $\begin{array}{c}5.00 \mathrm{e}-01 \\
(2.74 \mathrm{e}-08) \\
(7.27 \mathrm{e}-04)\end{array}$ & $\begin{array}{l}1.49 e+02 \\
(1.64 e-03) \\
(6.11 e-04)\end{array}$ & $\begin{array}{c}0.10 e+01 \\
(0) \\
(0)\end{array}$ \\
\hline & $\begin{array}{c}5.00 e-01 \\
(2.79 e-07) \\
(5.87 e-03)\end{array}$ & $\begin{array}{l}1.49 \mathrm{e}=02 \\
(2.18 \mathrm{e}-02) \\
(5.48 \mathrm{e}-03)\end{array}$ & $\begin{array}{c}0.19 \mathrm{e}=01 \\
(0) \\
(0)\end{array}$ & $\begin{array}{c}4.99 \mathrm{e}-01 \\
(3.52 \mathrm{e}-11) \\
(1.88 \mathrm{e}-04)\end{array}$ & $\begin{array}{c}1.50 \mathrm{e}+02 \\
(2.51 \mathrm{e}-06) \\
(1.67 \mathrm{e}-04)\end{array}$ & $\begin{array}{c}0.19 e+01 \\
(0) \\
(0)\end{array}$ \\
\hline \multirow{3}{*}{ WNISE } & $\begin{array}{c}5.01 \mathrm{e}-01 \\
(7.72 \mathrm{e}-07) \\
(1.58 \mathrm{e}-02)\end{array}$ & $\begin{array}{c}1.49 \mathrm{e}+02 \\
(7.95 \mathrm{e}-02) \\
(1.66 \mathrm{e}-02)\end{array}$ & $\begin{array}{c}4.95 e-01 \\
(0) \\
(0)\end{array}$ & $\begin{array}{c}5.00 \mathrm{e}-01 \\
(5.00 \mathrm{e}-08) \\
(1.19 \mathrm{e}-03)\end{array}$ & $\begin{array}{c}1.49 \mathrm{e}+02 \\
(5.95 \mathrm{e}-03) \\
(1.31 \mathrm{e}-03)\end{array}$ & $\begin{array}{c}95 e-01 \\
(0) \\
(0)\end{array}$ \\
\hline & $\begin{array}{c}5.01 \mathrm{e}-01 \\
(4.85 \mathrm{e}-07) \\
(1.01 \mathrm{e}-02)\end{array}$ & $\begin{array}{c}1.49 \mathrm{e}-02 \\
(3.69 \mathrm{e}-02) \\
(9.26 \mathrm{e}-03)\end{array}$ & $\begin{array}{c}0.10 \mathrm{e}=01 \\
(0) \\
(0)\end{array}$ & $\begin{array}{c}5.00 \mathrm{e}-01 \\
(4.07 \mathrm{e}-08) \\
(1.00 \mathrm{e}-03)\end{array}$ & $\begin{array}{l}1.49 e+02) \\
(2.77 e-03) \\
(8.91 e-04)\end{array}$ & $\begin{array}{c}(0.10 \mathrm{e}+01) \\
(0) \\
(0)\end{array}$ \\
\hline & $\begin{array}{c}5.01 \mathrm{e}-01 \\
(5.23 \mathrm{e}-07) \\
(1.08 \mathrm{e}-02)\end{array}$ & $\begin{array}{c}1.49 \mathrm{e}-02 \\
(4.13 \mathrm{e}-02) \\
(1.01 \mathrm{e}-02)\end{array}$ & $\begin{array}{c}0.20 \mathrm{e}=01 \\
(0) \\
(0)\end{array}$ & $\begin{array}{c}4.99 \mathrm{e}-01 \\
(2.84 \mathrm{e}-11) \\
(1.60 \mathrm{e}-04)\end{array}$ & $\begin{array}{l}1.50 e+02) \\
(2.27 e-06) \\
(1.51 e-04)\end{array}$ & $\begin{array}{c}(0.19 e+01) \\
(0) \\
(0)\end{array}$ \\
\hline
\end{tabular}


International Journal of Software Engineering \& Applications (IJSEA), Vol.7, No.3, May 2016

Table (2.a): Continued.

\begin{tabular}{|c|c|c|c|c|c|c|}
\hline \multirow{3}{*}{$\begin{array}{l}\text { Method of } \\
\text { estimation }\end{array}$} & \multicolumn{6}{|c|}{$\begin{array}{c}\text { Repetition }=5000 \\
\text { True parameters: } \varphi=0.5, N=150, \text { and } \beta=0.5,1,2 .\end{array}$} \\
\hline & \multicolumn{3}{|c|}{$\mathrm{n}=\mathbf{5 0}$} & \multicolumn{3}{|c|}{$\mathrm{n}=100$} \\
\hline & $\begin{array}{l}\quad \hat{\varphi} \\
\left(\operatorname{MSE}_{\hat{\phi}}\right) \\
\left(\operatorname{MAPE}_{\hat{\varphi}} \%\right)\end{array}$ & $\begin{array}{c}\hat{\boldsymbol{N}} \\
\left(\operatorname{MSE}_{\mathbb{N}_{n}}\right) \\
\left(\operatorname{MAPE}_{N_{0}} \%\right)\end{array}$ & $\begin{array}{c}\widehat{\widehat{\beta}} \\
\left(\mathbf{M S E}_{\tilde{\beta}}\right) \\
\left(\operatorname{MAPE}_{\tilde{\beta}} \%\right)\end{array}$ & $\begin{array}{l}\quad \hat{\varphi} \\
\left(\operatorname{MSE}_{\hat{\phi}}\right) \\
\left(\operatorname{MAPE}_{\hat{\varphi}} \%\right)\end{array}$ & $\begin{array}{c}\hat{\boldsymbol{N}} \\
\left(\mathrm{MSE}_{\bar{N}_{n}}\right) \\
\left(\operatorname{MAPE}_{\hat{N}_{0}} \%\right)\end{array}$ & $\begin{array}{c}\widehat{\hat{\boldsymbol{\beta}}} \\
\left(\mathbf{M S E}_{\tilde{\beta}}\right) \\
\left(\operatorname{MAPE}_{\tilde{\mathbf{\beta}}} \%\right)\end{array}$ \\
\hline \multirow{3}{*}{ MIE } & $\begin{array}{c}4.99 \mathrm{e}-01 \\
(2.05 \mathrm{e}-05) \\
(7.05 \mathrm{e}-02)\end{array}$ & $\begin{array}{c}1.47 \mathrm{e}+02 \\
(0.18 \mathrm{e}+01) \\
(3.98 \mathrm{e}-02)\end{array}$ & $\begin{array}{c}.65 \mathrm{e}-01 \\
(3.43 \mathrm{e}-05) \\
(1.41 \mathrm{e}-01)\end{array}$ & $\begin{array}{c}5.06 \mathrm{e}-01 \\
(3.05 \mathrm{e}-06) \\
(2.49 \mathrm{e}-02)\end{array}$ & $\begin{array}{c}1.49 \mathrm{e}+02 \\
(9.61 \mathrm{e}-02) \\
(6.24 \mathrm{e}-03)\end{array}$ & $\begin{array}{c}4.67 \mathrm{e}-01 \\
(1.32 \mathrm{e}-05) \\
(6.65 \mathrm{e}-02)\end{array}$ \\
\hline & $\begin{array}{c}4.79 \mathrm{e}-01 \\
(4.28 \mathrm{e}-05) \\
(1.23 \mathrm{e}-01)\end{array}$ & $\begin{array}{c}1.43 e+02 \\
(0.33 e+01) \\
(8.71 e-02)\end{array}$ & $\begin{array}{c}0.10 \mathrm{e}+01 \\
(1.15 \mathrm{e}-05) \\
(3.03 \mathrm{e}-02)\end{array}$ & $\begin{array}{c}4.85 \mathrm{e}-01 \\
(1.03 \mathrm{e}-05) \\
(4.67 \mathrm{e}-02)\end{array}$ & $\begin{array}{c}1.48 \mathrm{e}+02 \\
(1.85 \mathrm{e}-01) \\
(1.21 \mathrm{e}-02)\end{array}$ & $\begin{array}{c}0.10 \mathrm{e}+01 \\
(1.73 \mathrm{e}-06) \\
(1.09 \mathrm{e}-02)\end{array}$ \\
\hline & $\begin{array}{c}4.96 \mathrm{e}-01 \\
(2.30 \mathrm{e}-05) \\
(7.76 \mathrm{e}-02)\end{array}$ & $\begin{array}{c}1.46 \mathrm{e}+02 \\
(0.19 \mathrm{e}+01) \\
(4.97 \mathrm{e}-02)\end{array}$ & $\begin{array}{c}0.19 \mathrm{e}+01 \\
(1.68 \mathrm{e}-04) \\
(5.93 \mathrm{e}-02)\end{array}$ & $\begin{array}{c}5.04 \mathrm{e}-01 \\
(3.31 \mathrm{e}-06) \\
(2.57 \mathrm{e}-02)\end{array}$ & $\begin{array}{c}1.49 \mathrm{e}+02 \\
(1.03 \mathrm{e}-01) \\
(7.05 \mathrm{e}-03)\end{array}$ & $\begin{array}{c}0.19 \mathrm{e}+01 \\
(4.09 \mathrm{e}-05) \\
(2.26 \mathrm{e}-02)\end{array}$ \\
\hline \multirow{3}{*}{ NLSE } & $\begin{array}{c}4.99 \mathrm{e}-01 \\
(1.23 \mathrm{e}-09) \\
(1.68 \mathrm{e}-04)\end{array}$ & $\begin{array}{c}1.50 e+02 \\
(1.18 e-04) \\
(1.43 e-04)\end{array}$ & $\begin{array}{c}4.99 \mathrm{e}-01 \\
(0) \\
(0)\end{array}$ & $\begin{array}{c}4.99 \mathrm{e}-01 \\
(3.78 \mathrm{e}-11) \\
(1.03 \mathrm{e}-04)\end{array}$ & $\begin{array}{c}1.50 \mathrm{e}+02 \\
(9.95 \mathrm{e}-07) \\
(6.63 \mathrm{e}-05)\end{array}$ & $\begin{array}{c}5.05 e-01 \\
(0) \\
(0\end{array}$ \\
\hline & $\begin{array}{c}4.99 \mathrm{e}-01 \\
(2.27 \mathrm{e}-11) \\
(1.14 \mathrm{e}-04)\end{array}$ & $\begin{array}{l}1.50 e+02 \\
(1.45 e-06) \\
(9.66 e-05)\end{array}$ & $\begin{array}{c}9.99 \mathrm{e}-01 \\
(0) \\
(0)\end{array}$ & $\begin{array}{c}4.99 \mathrm{e}-01 \\
(2.33 \mathrm{e}-11) \\
(8.79 \mathrm{e}-05)\end{array}$ & $\begin{array}{c}1.50 e+02 \\
(8.40 e-07) \\
(5.60 e-05)\end{array}$ & $\begin{array}{c}9.95 \mathrm{e}-01 \\
(0) \\
(0)\end{array}$ \\
\hline & $\begin{array}{c}4.99 \mathrm{e}-01 \\
(2.89 \mathrm{e}-11) \\
(1.41 \mathrm{e}-04)\end{array}$ & $\begin{array}{c}1.50 \mathrm{e}+02 \\
(1.71 \mathrm{e}-06) \\
(1.14 \mathrm{e}-04)\end{array}$ & $\begin{array}{c}0.19 \mathrm{e}+01 \\
(0) \\
(0)\end{array}$ & $\begin{array}{c}4.99 \mathrm{e}-01) \\
(3.42 \mathrm{e}-11) \\
(1.16 \mathrm{e}-04)\end{array}$ & $\begin{array}{c}1.50 \mathrm{e}+02 \\
(9.93 \mathrm{e}-07) \\
(6.62 \mathrm{e}-05)\end{array}$ & $\begin{array}{c}0.19 e+01 \\
(0) \\
(0)\end{array}$ \\
\hline \multirow{3}{*}{ WNLSE } & $\begin{array}{c}.99 \mathrm{e}-01 \\
(4.02 \mathrm{e}-09) \\
(1.85 \mathrm{e}-04)\end{array}$ & $\begin{array}{c}1.50 \mathrm{e}+02 \\
(5.36 \mathrm{e}-04) \\
(2.04 \mathrm{e}-04)\end{array}$ & $\begin{array}{c}4.99 \mathrm{e}-01 \\
(0) \\
(0)\end{array}$ & $\begin{array}{c}.99 \mathrm{e}-01 \\
(1.43 \mathrm{e}-11) \\
(5.91 \mathrm{e}-05)\end{array}$ & $\begin{array}{c}1.50 \mathrm{e}+02 \\
(9.11 \mathrm{e}-07) \\
(6.07 \mathrm{e}-05)\end{array}$ & $\begin{array}{c}5.07 e-01 \\
(0) \\
(0)\end{array}$ \\
\hline & $\begin{array}{c}4.99 \mathrm{e}-01 \\
(8.19 \mathrm{e}-10) \\
(1.29 \mathrm{e}-04)\end{array}$ & $\begin{array}{c}1.50 \mathrm{e}+02 \\
(4.72 \mathrm{e}-05) \\
(1.22 \mathrm{e}-04)\end{array}$ & $\begin{array}{c}0.10 \mathrm{e}+01 \\
(0) \\
(0)\end{array}$ & $\begin{array}{c}4.99 \mathrm{e}-01 \\
(1.29 \mathrm{e}-11) \\
(6.78 \mathrm{e}-05)\end{array}$ & $\begin{array}{c}1.50 \mathrm{e}+02 \\
(8.97 \mathrm{e}-07) \\
(5.98 \mathrm{e}-05)\end{array}$ & $\begin{array}{c}9.99 \mathrm{e}-01 \\
(0) \\
(0)\end{array}$ \\
\hline & $\begin{array}{c}4.99 \mathrm{e}-01 \\
(2.05 \mathrm{e}-11) \\
(1.11 \mathrm{e}-04)\end{array}$ & $\begin{array}{c}1.50 \mathrm{e}+02 \\
(1.51 \mathrm{e}-06) \\
(1.01 \mathrm{e}-04)\end{array}$ & $\begin{array}{c}0.19 \mathrm{e}+01 \\
(0) \\
(0)\end{array}$ & $\begin{array}{c}4.99 \mathrm{e}-01 \\
(1.64 \mathrm{e}-11) \\
(7.72 \mathrm{e}-05)\end{array}$ & $\begin{array}{c}1.50 \mathrm{e}+02 \\
(9.16 \mathrm{e}-07) \\
(6.10 \mathrm{e}-05)\end{array}$ & $\begin{array}{c}0.19 e+01 \\
(0) \\
(0)\end{array}$ \\
\hline
\end{tabular}


International Journal of Software Engineering \& Applications (IJSEA), Vol.7, No.3, May 2016

Table (2.b): Scenario 2; $[\varphi=1.5, \mathrm{~N}=150$, and $\beta=0.5,1,2]$

\begin{tabular}{|c|c|c|c|c|c|c|}
\hline \multirow{3}{*}{$\begin{array}{l}\text { Method of } \\
\text { estimation }\end{array}$} & \multicolumn{6}{|c|}{$\begin{array}{c}\text { Repetition }=5000 \\
\text { True parameters: } \varphi=1.5, N=150 \text {, and } \beta=0.5,1,2 .\end{array}$} \\
\hline & \multicolumn{3}{|c|}{$\mathrm{n}=15$} & \multicolumn{3}{|c|}{$\mathrm{n}=\mathbf{3 0}$} \\
\hline & $\begin{array}{c}\hat{\hat{\varphi}} \\
\left(\operatorname{MSE}_{\hat{\phi}}\right) \\
\left(\operatorname{MAPE}_{\hat{\phi}} \%\right)\end{array}$ & $\begin{array}{c}\widehat{\boldsymbol{N}} \\
\left(\mathrm{MSE}_{\widehat{N_{0}}}\right) \\
\left(\operatorname{MAPE}_{\hat{N}_{0}} \%\right)\end{array}$ & $\begin{array}{c}\widehat{\boldsymbol{\beta}} \\
\left(\mathbf{M S E}_{\tilde{i}}\right) \\
\left(\operatorname{MAPE}_{\hat{\boldsymbol{\beta}}} \%\right)\end{array}$ & $\begin{array}{c}\hat{\hat{\varphi}} \\
\left(\mathrm{MSE}_{\hat{\phi}}\right) \\
\left(\operatorname{MAPE}_{\hat{\phi}} \%\right)\end{array}$ & $\begin{array}{c}\widehat{\boldsymbol{N}} \\
\left(\operatorname{MSE}_{\widehat{N_{0}}}\right) \\
\left(\operatorname{MAPE}_{\widehat{N}_{0}} \%\right)\end{array}$ & $\begin{array}{c}\widehat{\boldsymbol{\beta}} \\
\left(\mathbf{M S E}_{\tilde{\tilde{\beta}}}\right) \\
\left(\operatorname{MAPE}_{\tilde{\mathbf{\beta}}} \%\right)\end{array}$ \\
\hline \multirow{3}{*}{ MIE } & $\begin{array}{c}0.14 \mathrm{e}+01 \\
(2.94 \mathrm{e}-03) \\
(3.76 \mathrm{e}-01)\end{array}$ & $\begin{array}{c}1.42 \mathrm{e}+02 \\
(3.52 \mathrm{e}+01) \\
(3.39 \mathrm{e}-01)\end{array}$ & $\begin{array}{c}4.59 \mathrm{e}-01 \\
(2.09 \mathrm{e}-04) \\
(5.60 \mathrm{e}-01\end{array}$ & $\begin{array}{c}0.14 \mathrm{e}+01 \\
(8.54 \mathrm{e}-04) \\
(1.41 \mathrm{e}-01)\end{array}$ & $\begin{array}{c}1.44 \mathrm{e}+02 \\
(1.07 \mathrm{e}+01) \\
(1.43 \mathrm{e}-01)\end{array}$ & $\begin{array}{c}4.65 \mathrm{e}-01 \\
(6.88 \mathrm{e}-05) \\
(2.42 \mathrm{e}-01)\end{array}$ \\
\hline & $\begin{array}{c}0.13 \mathrm{e}+01 \\
(4.93 \mathrm{e}-03) \\
(7.26 \mathrm{e}-01)\end{array}$ & $\begin{array}{c}1.35 \mathrm{e}+02 \\
(5.61 \mathrm{e}+01) \\
(6.61 \mathrm{e}-01)\end{array}$ & $\begin{array}{c}9.84 e-01 \\
(2.07 e-04) \\
(1.95 e-01)\end{array}$ & $\begin{array}{c}0.14 \mathrm{e}+01 \\
(1.69 \mathrm{e}-03) \\
(3.16 \mathrm{e}-01)\end{array}$ & $\begin{array}{c}1.37 \mathrm{e}+02 \\
(1.81 \mathrm{e}+01) \\
(2.89 \mathrm{e}-01)\end{array}$ & $\begin{array}{c}9.95 \mathrm{e}-01 \\
(3.97 \mathrm{e}-05) \\
(6.56 \mathrm{e}-02)\end{array}$ \\
\hline & $\begin{array}{c}0.14 \mathrm{e}+01 \\
(3.31 \mathrm{e}-03) \\
(4.75 \mathrm{e}-01)\end{array}$ & $\begin{array}{c}1.39 e+02 \\
(4.21 e+01) \\
(4.66 e-01)\end{array}$ & $\begin{array}{c}0.19 \mathrm{e}+01 \\
(1.68 \mathrm{e}-03) \\
(3.11 \mathrm{e}-01)\end{array}$ & $\begin{array}{c}0.14 \mathrm{e}+01 \\
(9.84 \mathrm{e}-04) \\
(1.79 \mathrm{e}-01)\end{array}$ & $\begin{array}{c}1.42 \mathrm{e}+02 \\
(1.21 \mathrm{e}+01) \\
(1.82 \mathrm{e}-01)\end{array}$ & $\begin{array}{c}0.19 \mathrm{e}+01 \\
(4.26 \mathrm{e}-04) \\
(1.14 \mathrm{e}-01)\end{array}$ \\
\hline \multirow{3}{*}{ NLSE } & $\begin{array}{c}0.15 e+01 \\
(8.46 e-07) \\
(6.00 e-03)\end{array}$ & $\begin{array}{c}1.49 \mathrm{e}+02 \\
(9.91 \mathrm{e}-03) \\
(6.38 \mathrm{e}-03)\end{array}$ & $\begin{array}{c}.94 \mathrm{e}-01 \\
(0) \\
(0)\end{array}$ & $\begin{array}{c}0.15 \mathrm{e}+01 \\
(8.31 \mathrm{e}-08) \\
(7.72 \mathrm{e}-04)\end{array}$ & $\begin{array}{c}1.49 e+02 \\
(9.70 e-04) \\
(7.79 e-04)\end{array}$ & $\begin{array}{c}4.95 \mathrm{e}-01 \\
(0) \\
(0)\end{array}$ \\
\hline & $\begin{array}{c}0.15 \mathrm{e}+01 \\
(1.79 \mathrm{e}-07) \\
(1.64 \mathrm{e}-03)\end{array}$ & $\begin{array}{c}1.49 \mathrm{e}+02 \\
(1.45 \mathrm{e}-03) \\
(1.49 \mathrm{e}-03)\end{array}$ & $\begin{array}{c}0.10 \mathrm{e}+01 \\
(0) \\
(0)\end{array}$ & $\begin{array}{c}0.15 \mathrm{e}+01 \\
(1.11 \mathrm{e}-08) \\
(3.12 \mathrm{e}-04)\end{array}$ & $\begin{array}{c}1.50 \mathrm{e}+02 \\
(7.51 \mathrm{e}-05) \\
(2.75 \mathrm{e}-04)\end{array}$ & $\begin{array}{c}0.10 \mathrm{e}+01 \\
(0) \\
(0)\end{array}$ \\
\hline & $\begin{array}{c}0.15 e+01 \\
(1.67 e-07) \\
(1.49 e-03)\end{array}$ & $\begin{array}{c}1.49 \mathrm{e}+02 \\
(1.40 \mathrm{e}-03) \\
(1.38 \mathrm{e}-03)\end{array}$ & $\begin{array}{c}0.20 \mathrm{e}+01 \\
(0) \\
(0)\end{array}$ & $\begin{array}{c}0.15 e+01 \\
(3.77 e-10) \\
(2.24 e-04)\end{array}$ & $\begin{array}{c}1.50 e+02 \\
(2.99 e-06) \\
(1.99 e-04)\end{array}$ & $\begin{array}{c}0.19 e+01 \\
(0) \\
(0)\end{array}$ \\
\hline \multirow{3}{*}{ WNLSE } & $\begin{array}{c}0.15 \mathrm{e}+01 \\
(8.83 \mathrm{e}-07) \\
(6.22 \mathrm{e}-03)\end{array}$ & $\begin{array}{c}1.49 \mathrm{e}+02 \\
(1.13 \mathrm{e}-02) \\
(6.89 \mathrm{e}-03)\end{array}$ & $\begin{array}{c}4.95 \mathrm{e}-01 \\
(0) \\
(0)\end{array}$ & $\begin{array}{c}0.15 e+01 \\
(8.76 e-08) \\
(7.65 e-04)\end{array}$ & $\begin{array}{c}1.49 \mathrm{e}+02 \\
(1.33 \mathrm{e}-03) \\
(8.89 \mathrm{e}-04)\end{array}$ & $\begin{array}{c}4.95 e-01 \\
(0) \\
(0)\end{array}$ \\
\hline & $\begin{array}{c}0.15 e+01 \\
(1.66 e-07) \\
(1.54 e-03)\end{array}$ & $\begin{array}{c}1.49 e+02 \\
(1.42 e-03) \\
(1.45 e-03)\end{array}$ & $\begin{array}{c}0.10 \mathrm{e}+01 \\
(0) \\
(0)\end{array}$ & $\begin{array}{c}0.15 e+01 \\
(1.17 e-08) \\
(3.00 e-04)\end{array}$ & $\begin{array}{c}1.50 \mathrm{e}+02 \\
(9.05 \mathrm{e}-05) \\
(2.85 \mathrm{e}-04)\end{array}$ & $\begin{array}{c}0.10 \mathrm{e}+01 \\
(0) \\
(0)\end{array}$ \\
\hline & $\begin{array}{c}0.15 e+01 \\
(4.27 e-07) \\
(3.19 e-03)\end{array}$ & $\begin{array}{c}1.49 e+02 \\
(3.76 e-03) \\
(3.01 e-03)\end{array}$ & $\begin{array}{c}0.20 \mathrm{e}+01 \\
(0) \\
(0)\end{array}$ & $\begin{array}{c}0.15 e+01 \\
(1.65 e-09) \\
(2.07 e-04)\end{array}$ & $\begin{array}{c}1.50 e+02 \\
(1.32 e-05) \\
(1.95 e-04)\end{array}$ & $\begin{array}{c}0.19 \mathrm{e}+01 \\
(0) \\
(0)\end{array}$ \\
\hline
\end{tabular}


International Journal of Software Engineering \& Applications (IJSEA), Vol.7, No.3, May 2016

Table (2.b): Continued.

\begin{tabular}{|c|c|c|c|c|c|c|}
\hline \multirow{3}{*}{$\begin{array}{l}\text { Method of } \\
\text { estimation }\end{array}$} & \multicolumn{6}{|c|}{$\begin{array}{c}\text { Repetition }=5000 \\
\text { True parameters: } \varphi=1.5, N=150 \text {, and } \beta=0.5,1,2 .\end{array}$} \\
\hline & \multicolumn{3}{|c|}{$\mathrm{n}=\mathbf{5 0}$} & \multicolumn{3}{|c|}{$\mathrm{n}=100$} \\
\hline & $\begin{array}{l}\hat{\hat{\varphi}} \\
\left(\operatorname{MSE}_{\hat{\phi}}\right) \\
\left(\operatorname{MAPE}_{\hat{\phi}} \%\right)\end{array}$ & $\begin{array}{c}\hat{N} \\
\left(\operatorname{MSE}_{\hat{N}_{a}}\right) \\
\left(\operatorname{MAPE}_{N_{0}} \%\right)\end{array}$ & $\begin{array}{c}\widehat{\hat{\boldsymbol{\beta}}} \\
\left(\mathrm{MSE}_{\tilde{\beta}}\right) \\
\left(\mathrm{MAPE}_{\hat{\boldsymbol{\beta}}} \%\right)\end{array}$ & 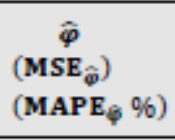 & $\begin{array}{c}\hat{\boldsymbol{N}} \\
\left(\mathrm{MSE}_{\bar{N}_{0}}\right) \\
\left(\operatorname{MAPE}_{\tilde{N}_{0}} \%\right)\end{array}$ & $\begin{array}{c}\widehat{\hat{\boldsymbol{\beta}}} \\
\left(\mathrm{MSE}_{\tilde{\hat{\beta}}}\right) \\
\left(\mathrm{MAPE}_{\tilde{\mathbf{\beta}}} \%\right)\end{array}$ \\
\hline \multirow{3}{*}{ MILE } & $\begin{array}{c}0.15 \mathrm{e}+01 \\
(3.40 \mathrm{e}-04) \\
(6.83 \mathrm{e}-02)\end{array}$ & $\begin{array}{c}1.46 \mathrm{e}+02 \\
(0.31 \mathrm{e}+01) \\
(5.85 \mathrm{e}-02)\end{array}$ & $\begin{array}{c}4.67 \mathrm{e}-01 \\
(3.11 \mathrm{e}-05 \\
(1.32 \mathrm{e}-01)\end{array}$ & $\begin{array}{c}0.15 \mathrm{e}+01 \\
(5.74 \mathrm{e}-05) \\
(2.02 \mathrm{e}-02)\end{array}$ & $\begin{array}{c}1.49 \mathrm{e}+02 \\
(1.74 \mathrm{e}-01) \\
(9.59 \mathrm{e}-03)\end{array}$ & $\begin{array}{c}.69 \mathrm{e}-01 \\
(1.09 \mathrm{e}-05) \\
(6.04 \mathrm{e}-02)\end{array}$ \\
\hline & $\begin{array}{c}0.14 \mathrm{e}+01 \\
(8.19 \mathrm{e}-04) \\
(1.83 \mathrm{e}-01)\end{array}$ & $\begin{array}{c}1.40 \mathrm{e}+02 \\
(0.58 \mathrm{e}+01) \\
(1.27 \mathrm{e}-01)\end{array}$ & $\begin{array}{c}0.10 \mathrm{e}+01 \\
(1.11 \mathrm{e}-05) \\
(2.98 \mathrm{e}-02)\end{array}$ & $\begin{array}{c}0.14 \mathrm{e}+01 \\
(2.88 \mathrm{e}-04) \\
(9.09 \mathrm{e}-02)\end{array}$ & $\begin{array}{c}1.47 \mathrm{e}+02 \\
(3.22 \mathrm{e}-01) \\
(1.74 \mathrm{e}-02)\end{array}$ & $\begin{array}{c}0.10 \mathrm{e}+01 \\
(1.59 \mathrm{e}-06) \\
(1.07 \mathrm{e}-02)\end{array}$ \\
\hline & $\begin{array}{c}0.15 \mathrm{e}+01 \\
(3.88 \mathrm{e}-04) \\
(8.59 \mathrm{e}-02)\end{array}$ & $\begin{array}{c}1.45 \mathrm{e}+02 \\
(0.34 \mathrm{e}+01) \\
(7.22 \mathrm{e}-02)\end{array}$ & $\begin{array}{c}0.19 \mathrm{e}+01 \\
(1.49 \mathrm{e}-04) \\
(5.23 \mathrm{e}-02)\end{array}$ & $\begin{array}{c}0.15 \mathrm{e}+01 \\
(6.63 \mathrm{e}-05) \\
(2.49 \mathrm{e}-02)\end{array}$ & $\begin{array}{c}1.48 \mathrm{e}+02 \\
(1.86 \mathrm{e}-01) \\
(1.08 \mathrm{e}-02)\end{array}$ & $\begin{array}{c}0.19 \mathrm{e}+01 \\
(2.89 \mathrm{e}-05) \\
(1.74 \mathrm{e}-02)\end{array}$ \\
\hline \multirow{3}{*}{ NLSE } & $\begin{array}{c}0.15 \mathrm{e}+01 \\
(1.19 \mathrm{e}-08) \\
(2.25 \mathrm{e}-04)\end{array}$ & $\begin{array}{c}1.50 e+02 \\
(1.50 e-04) \\
(2.06 e-04)\end{array}$ & $\begin{array}{c}4.99 \mathrm{e}-01 \\
(0) \\
(0)\end{array}$ & $\begin{array}{c}0.15 \mathrm{e}+01 \\
(4.11 \mathrm{e}-10) \\
(1.12 \mathrm{e}-04)\end{array}$ & $\begin{array}{c}1.50 e+02 \\
(9.96 e-07) \\
(6.64 e-05)\end{array}$ & $\begin{array}{c}5.05 e-01 \\
(0) \\
(0)\end{array}$ \\
\hline & $\begin{array}{c}0.15 e+01 \\
(2.94 e-10) \\
(1.59 e-04)\end{array}$ & $\begin{array}{l}1.50 e+02 \\
(1.97 e-06) \\
(1.31 e-04)\end{array}$ & $\begin{array}{c}9.99 \mathrm{e}-01 \\
(0) \\
(0)\end{array}$ & $\begin{array}{c}0.15 e+01 \\
(2.60 e-10) \\
(1.05 e-04)\end{array}$ & $\begin{array}{c}1.50 \mathrm{e}+02 \\
(9.66 \mathrm{e}-07) \\
(6.44 \mathrm{e}-05)\end{array}$ & $\begin{array}{c}9.94 \mathrm{e}-01 \\
(0) \\
(0)\end{array}$ \\
\hline & $\begin{array}{c}0.15 e+01 \\
(2.92 e-10) \\
(1.57 e-04)\end{array}$ & $\begin{array}{c}1.50 \mathrm{e}+02 \\
(1.89 \mathrm{e}-06) \\
(1.26 \mathrm{e}-04)\end{array}$ & $\begin{array}{c}0.19 \mathrm{e}+01 \\
(0) \\
(0)\end{array}$ & $\begin{array}{c}0.15 \mathrm{e}+01 \\
(3.33 \mathrm{e}-10) \\
(1.21 \mathrm{e}-04)\end{array}$ & $\begin{array}{c}1.50 \mathrm{e}+02 \\
(9.89 \mathrm{e}-07) \\
(6.59 \mathrm{e}-05)\end{array}$ & $\begin{array}{c}0.19 \mathrm{e}+01 \\
(0) \\
(0)\end{array}$ \\
\hline \multirow{3}{*}{ WNLSE } & $\begin{array}{c}0.15 \mathrm{e}+01 \\
(1.22 \mathrm{e}-08) \\
(1.85 \mathrm{e}-04)\end{array}$ & $\begin{array}{c}1.50 \mathrm{e}+02 \\
(2.24 \mathrm{e}-04) \\
(2.16 \mathrm{e}-04)\end{array}$ & $\begin{array}{c}4.99 \mathrm{e}-01 \\
(0) \\
(0)\end{array}$ & $\begin{array}{c}0.15 e+01 \\
(9.54 e-10) \\
(6.85 e-05)\end{array}$ & $\begin{array}{c}1.50 \mathrm{e}+02 \\
(7.31 \mathrm{e}-05) \\
(7.46 \mathrm{e}-05)\end{array}$ & $\begin{array}{c}5.06 e-01 \\
(0) \\
(0)\end{array}$ \\
\hline & $\begin{array}{c}0.15 e+01 \\
(2.22 e-10) \\
(1.39 e-04)\end{array}$ & $\begin{array}{c}1.50 \mathrm{e}+02 \\
(1.97 \mathrm{e}-06) \\
(1.32 \mathrm{e}-04)\end{array}$ & $\begin{array}{c}0.10 \mathrm{e}+01 \\
(0) \\
(0)\end{array}$ & $\begin{array}{c}0.15 e+01 \\
(1.34 e-10) \\
(7.62 e-05)\end{array}$ & $\begin{array}{c}1.50 \mathrm{e}+02 \\
(9.97 \mathrm{e}-07) \\
(6.64 \mathrm{e}-05)\end{array}$ & $\begin{array}{c}9.99 \mathrm{e}-01 \\
(0) \\
(0)\end{array}$ \\
\hline & $\begin{array}{c}0.15 e+01 \\
(2.19 e-10) \\
(1.32 e-04)\end{array}$ & $\begin{array}{c}1.50 e+02 \\
(1.79 e-06) \\
(1.19 e-04)\end{array}$ & $\begin{array}{c}0.19 \mathrm{e}+01 \\
(0) \\
(0)\end{array}$ & $\begin{array}{c}0.15 e+01 \\
(1.64 e-10) \\
(8.37 e-05)\end{array}$ & $\begin{array}{c}1.50 \mathrm{e}+02 \\
(9.72 \mathrm{e}-07) \\
(6.48 \mathrm{e}-05)\end{array}$ & $\begin{array}{c}0.19 \mathrm{e}+01 \\
(0) \\
(0)\end{array}$ \\
\hline
\end{tabular}


International Journal of Software Engineering \& Applications (IJSEA), Vol.7, No.3, May 2016

Table (2.c): Scenario 3:[ $\varphi=0.5, \mathrm{~N}=250$, and $\beta=0.5,1,2]$.

\begin{tabular}{|c|c|c|c|c|c|c|}
\hline \multirow{3}{*}{$\begin{array}{l}\text { Method of } \\
\text { estimation }\end{array}$} & \multicolumn{6}{|c|}{$\begin{array}{l}\text { Repetition }=5000 \\
\text { True parameters: } \varphi=0.5, N=250 \text {, and } \beta=0.5,1,2 \text {. }\end{array}$} \\
\hline & \multicolumn{3}{|c|}{$\mathrm{n}=15$} & \multicolumn{3}{|c|}{$\mathrm{n}=\mathbf{3 0}$} \\
\hline & $\begin{array}{l}\quad \hat{\varphi} \\
\left(\mathrm{MSE}_{\hat{\varphi}}\right) \\
\left(\mathrm{MAPE}_{\hat{\varphi}} \%\right)\end{array}$ & $\begin{array}{c}\widehat{N} \\
\left(\operatorname{MSE}_{\widehat{N_{0}}}\right) \\
\left(\operatorname{MAPE}_{\bar{N}_{0}} \%\right)\end{array}$ & $\begin{array}{c}\widehat{\hat{\boldsymbol{\beta}}} \\
\left(\mathrm{MSE}_{\hat{\beta}}\right) \\
\left(\mathrm{MAPE}_{\hat{\beta}} \%\right)\end{array}$ & $\begin{array}{l}\quad \hat{\varphi} \\
\left(\mathrm{MSE}_{\hat{\varphi}}\right) \\
\left(\mathrm{MAPE}_{\hat{\varphi}} \%\right)\end{array}$ & $\begin{array}{c}\hat{\boldsymbol{N}} \\
\left(\operatorname{MSE}_{\bar{N}_{0}}\right) \\
\left(\operatorname{MAPE}_{\hat{N}_{0}} \%\right)\end{array}$ & $\begin{array}{c}\widehat{\hat{\boldsymbol{\beta}}} \\
\left(\mathrm{MSE}_{\tilde{\tilde{\beta}}}\right) \\
\left(\mathrm{MAPE}_{\tilde{\beta}} \%\right)\end{array}$ \\
\hline \multirow{3}{*}{ MIE } & $\begin{array}{c}4.79 \mathrm{e}-01 \\
(3.44 \mathrm{e}-04) \\
(4.72 \mathrm{e}-01)\end{array}$ & $\begin{array}{c}2.42 \mathrm{e}+02 \\
(6.08 \mathrm{e}+01) \\
(2.24 \mathrm{e}-01)\end{array}$ & $\begin{array}{c}4.61 \mathrm{e}-01 \\
(2.05 \mathrm{e}-04) \\
(5.54 \mathrm{e}-01)\end{array}$ & $\begin{array}{c}4.91 \mathrm{e}-01 \\
(8.57 \mathrm{e}-05) \\
(1.69 \mathrm{e}-01)\end{array}$ & $\begin{array}{c}2.41 \mathrm{e}+02 \\
(2.44 \mathrm{e}+01) \\
(1.14 \mathrm{e}-01)\end{array}$ & $\begin{array}{c}4.66 \mathrm{e}-01 \\
(6.66 \mathrm{e}-05) \\
(2.36 \mathrm{e}-01)\end{array}$ \\
\hline & $\begin{array}{c}4.52 \mathrm{e}-01 \\
(5.18 \mathrm{e}-04) \\
(7.68 \mathrm{e}-01)\end{array}$ & $\begin{array}{c}2.31 \mathrm{e}+02 \\
(1.13 \mathrm{e}+02) \\
(4.95 \mathrm{e}-01)\end{array}$ & $\begin{array}{l}(9.84 \mathrm{e}-01 \\
(1.98 \mathrm{e}-04) \\
(1.93 \mathrm{e}-01)\end{array}$ & $\begin{array}{c}4.65 \mathrm{e}-01 \\
(1.56 \mathrm{e}-04) \\
(3.02 \mathrm{e}-01)\end{array}$ & $\begin{array}{c}2.30 \mathrm{e}+02 \\
(4.69 \mathrm{e}+01) \\
(2.63 \mathrm{e}-01)\end{array}$ & $\begin{array}{c}9.96 e-01 \\
(3.78 e-05) \\
(6.39 e-02)\end{array}$ \\
\hline & $\begin{array}{c}4.74 \mathrm{e}-01 \\
(3.39 \mathrm{e}-04) \\
(5.24 \mathrm{e}-01)\end{array}$ & $\begin{array}{c}2.36 \mathrm{e}+02 \\
(9.29 \mathrm{e}+02) \\
(3.83 \mathrm{e}-01)\end{array}$ & $\begin{array}{c}0.19 \mathrm{e}+01 \\
(1.64 \mathrm{e}-03) \\
(3.09 \mathrm{e}-01)\end{array}$ & $\begin{array}{c}4.85 \mathrm{e}-01 \\
(9.12 \mathrm{e}-05) \\
(1.91 \mathrm{e}-01)\end{array}$ & $\begin{array}{c}2.37 e+02 \\
(3.11 e+01) \\
(1.67 e-01)\end{array}$ & $\begin{array}{c}0.19 \mathrm{e}+01 \\
(4.10 \mathrm{e}-04) \\
(1.11 \mathrm{e}-01)\end{array}$ \\
\hline \multirow{3}{*}{ NLSE } & $\begin{array}{c}5.02 \mathrm{e}-01 \\
(1.14 \mathrm{e}-06) \\
(2.29 \mathrm{e}-02)\end{array}$ & $\begin{array}{l}2.49 \mathrm{e}+02 \\
(3.01 \mathrm{e}-01) \\
(2.34 \mathrm{e}-02)\end{array}$ & $\begin{array}{c}4.95 \mathrm{e}-01 \\
(0) \\
(0)\end{array}$ & $\begin{array}{c}5.00 \mathrm{e}-01 \\
(1.67 \mathrm{e}-07) \\
(3.45 \mathrm{e}-03)\end{array}$ & $\begin{array}{c}2.49 e+02 \\
(4.54 e-02) \\
(3.54 e-03)\end{array}$ & $\begin{array}{c}4.95 \mathrm{e}-01 \\
(0) \\
(0)\end{array}$ \\
\hline & $\begin{array}{c}5.01 \mathrm{e}-01 \\
(6.67 \mathrm{e}-07) \\
(1.36 \mathrm{e}-02)\end{array}$ & $\begin{array}{l}2.49 \mathrm{e}+02 \\
(1.41 \mathrm{e}-01) \\
(1.24 \mathrm{e}-02)\end{array}$ & $\begin{array}{c}0.10 \mathrm{e}+01 \\
(0) \\
(0)\end{array}$ & $\begin{array}{c}5.00 \mathrm{e}-01 \\
(6.93 \mathrm{e}-08) \\
(1.52 \mathrm{e}-03)\end{array}$ & $\begin{array}{c}2.49 \mathrm{e}+02 \\
(1.34 \mathrm{e}-05) \\
(1.34 \mathrm{e}-03)\end{array}$ & $\begin{array}{c}0.10 \mathrm{e}+01 \\
(0) \\
(0)\end{array}$ \\
\hline & $\begin{array}{c}5.01 \mathrm{e}-01 \\
(3.60 \mathrm{e}-07) \\
(7.40 \mathrm{e}-03)\end{array}$ & $\begin{array}{l}2.49 \mathrm{e}+02 \\
(8.04 \mathrm{e}-02) \\
(6.99 \mathrm{e}-03)\end{array}$ & $\begin{array}{c}0.20 \mathrm{e}+01 \\
(0) \\
(0)\end{array}$ & $\begin{array}{c}4.99 \mathrm{e}-01 \\
(1.25 \mathrm{e}-11) \\
(1.17 \mathrm{e}-04)\end{array}$ & $\begin{array}{c}2.50 \mathrm{e}+02 \\
(2.75 \mathrm{e}-06) \\
(1.10 \mathrm{e}-04)\end{array}$ & $\begin{array}{c}0.19 \mathrm{e}+01 \\
(0) \\
(0)\end{array}$ \\
\hline \multirow{3}{*}{ WNLSE } & $\begin{array}{c}5.02 \mathrm{e}-01 \\
(1.16 \mathrm{e}-06) \\
(2.33 \mathrm{e}-02)\end{array}$ & $\begin{array}{c}2.49 \mathrm{e}+02 \\
(3.20 \mathrm{e}-01) \\
(2.43 \mathrm{e}-02)\end{array}$ & $\begin{array}{c}4.95 \mathrm{e}-01 \\
(0) \\
(0)\end{array}$ & $\begin{array}{c}5.00 \mathrm{e}-01 \\
(1.99 \mathrm{e}-07) \\
(4.07 \mathrm{e}-03)\end{array}$ & $\begin{array}{c}2.49 \mathrm{e}+02 \\
(6.14 \mathrm{e}-02) \\
(4.44 \mathrm{e}-03)\end{array}$ & $\begin{array}{c}4.95 \mathrm{e}-0 \mathrm{l} \\
(0) \\
(0)\end{array}$ \\
\hline & $\begin{array}{c}5.01 \mathrm{e}-01 \\
(3.73 \mathrm{e}-07) \\
(7.72 \mathrm{e}-03)\end{array}$ & $\begin{array}{c}2.49 \mathrm{e}+02 \\
(8.27 \mathrm{e}-02) \\
(7.23 \mathrm{e}-03)\end{array}$ & $\begin{array}{c}0.10 \mathrm{e}+01 \\
(0) \\
(0)\end{array}$ & $\begin{array}{c}5.00 \mathrm{e}-01 \\
(8.73 \mathrm{e}-08) \\
(1.87 \mathrm{e}-03)\end{array}$ & $\begin{array}{c}2.49 \mathrm{e}+02 \\
(1.84 \mathrm{e}-02) \\
(1.73 \mathrm{e}-03)\end{array}$ & $\begin{array}{c}0.10 \mathrm{e}+01 \\
(0) \\
(0)\end{array}$ \\
\hline & $\begin{array}{c}5.01 \mathrm{e}-01 \\
(7.44 \mathrm{e}-07) \\
(1.51 \mathrm{e}-02)\end{array}$ & $\begin{array}{c}2.49 \mathrm{e}+02 \\
(1.69 \mathrm{e}-01) \\
(1.44 \mathrm{e}-02)\end{array}$ & $\begin{array}{c}0.20 \mathrm{e}+01 \\
(0) \\
(0)\end{array}$ & $\begin{array}{c}4.99 \mathrm{e}-01 \\
(4.68 \mathrm{e}-09) \\
(1.95 \mathrm{e}-04)\end{array}$ & $\begin{array}{c}2.50 \mathrm{e}+02 \\
(1.02 \mathrm{e}-03) \\
(1.86 \mathrm{e}-04)\end{array}$ & $\begin{array}{c}0.20 \mathrm{e}+01 \\
(0) \\
(0)\end{array}$ \\
\hline
\end{tabular}


International Journal of Software Engineering \& Applications (IJSEA), Vol.7, No.3, May 2016

Table (2.c): Continued

\begin{tabular}{|c|c|c|c|c|c|c|}
\hline \multirow{3}{*}{$\begin{array}{l}\text { Method of } \\
\text { estimation }\end{array}$} & \multicolumn{6}{|c|}{$\begin{array}{c}\text { Repetition }=5000 \\
\text { True parameters: } \varphi=0.5, N=250 \text {, and } \beta=0.5,1,2 .\end{array}$} \\
\hline & \multicolumn{3}{|c|}{$\mathrm{n}=\mathbf{5 0}$} & \multicolumn{3}{|c|}{$\mathrm{n}=100$} \\
\hline & $\begin{array}{l}\quad \hat{\varphi} \\
\left(\operatorname{MSE}_{\hat{\phi}}\right) \\
\left(\operatorname{MAPE}_{\hat{\varphi}} \%\right)\end{array}$ & $\begin{array}{c}\hat{\boldsymbol{N}} \\
\left(\mathrm{MSE}_{\bar{N}_{\mathrm{a}}}\right) \\
\left(\mathrm{MAPE}_{N_{0}} \%\right)\end{array}$ & $\begin{array}{c}\widehat{\hat{\boldsymbol{\beta}}} \\
\left(\mathbf{M S E}_{\tilde{\beta}}\right) \\
\left(\text { MAPE }_{\tilde{\beta}} \%\right)\end{array}$ & $\begin{array}{l}\quad \hat{\varphi} \\
\left(\operatorname{MSE}_{\hat{\phi}}\right) \\
\left(\operatorname{MAPE}_{\hat{\varphi}} \%\right)\end{array}$ & 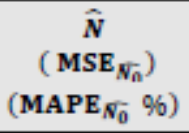 & $\begin{array}{c}\widehat{\boldsymbol{\beta}} \\
\left(\mathbf{M S E}_{\tilde{\mathbb{\beta}}}\right) \\
\left(\mathrm{MAPE}_{\tilde{\beta}} \%\right)\end{array}$ \\
\hline \multirow{3}{*}{ MIE } & $\begin{array}{c}4.96 \mathrm{e}-01 \\
(3.13 \mathrm{e}-05) \\
(8.25 \mathrm{e}-02)\end{array}$ & $\begin{array}{c}2.43 \mathrm{e}+02 \\
(0.91 \mathrm{e}+01) \\
(5.42 \mathrm{e}-02)\end{array}$ & $\begin{array}{c}4.69 \mathrm{e}-01 \\
(3.02 \mathrm{e}-05) \\
(1.28 \mathrm{e}-01)\end{array}$ & $\begin{array}{c}5.02 \mathrm{e}-01 \\
(6.04 \mathrm{e}-06) \\
(3.01 \mathrm{e}-02)\end{array}$ & $\begin{array}{c}2.46 \mathrm{e}+02 \\
(0.16 \mathrm{e}+01) \\
(1.72 \mathrm{e}-02\end{array}$ & $\begin{array}{c}4.71 \mathrm{e}-01 \\
(1.08 \mathrm{e}-05) \\
(5.82 \mathrm{e}-02)\end{array}$ \\
\hline & $\begin{array}{c}4.69 \mathrm{e}-01 \\
(6.99 \mathrm{e}-05) \\
(1.63 \mathrm{e}-01)\end{array}$ & $\begin{array}{c}2.33 e+02 \\
(1.94 e+01) \\
(1.39 e-01)\end{array}$ & $\begin{array}{c}0.10 \mathrm{e}+01 \\
(1.14 \mathrm{e}-05) \\
(2.97 \mathrm{e}-02)\end{array}$ & $\begin{array}{c}4.70 \mathrm{e}-01 \\
(2.34 \mathrm{e}-05) \\
(7.36 \mathrm{e}-02\end{array}$ & $\begin{array}{c}2.39 \mathrm{e}+02 \\
(0.39 \mathrm{e}+01) \\
(4.49 \mathrm{e}-02\end{array}$ & $\begin{array}{c}0.10 \mathrm{e}+01 \\
(1.96 \mathrm{e}-05) \\
(1.13 \mathrm{e}-02)\end{array}$ \\
\hline & $\begin{array}{c}4.91 \mathrm{e}-01 \\
(3.48 \mathrm{e}-05) \\
(9.31 \mathrm{e}-02)\end{array}$ & $\begin{array}{c}2.41 \mathrm{e}+02 \\
(1.06 \mathrm{e}+01) \\
(7.43 \mathrm{e}-02)\end{array}$ & $\begin{array}{c}0.19 \mathrm{e}+01 \\
(1.48 \mathrm{e}-04) \\
(5.11 \mathrm{e}-02)\end{array}$ & $\begin{array}{c}4.98 \mathrm{e}-01 \\
(6.81 \mathrm{e}-06) \\
(3.25 \mathrm{e}-02)\end{array}$ & $\begin{array}{c}2.45 e+02 \\
(0.18 \mathrm{e}+01) \\
(2.15 \mathrm{e}-02)\end{array}$ & $\begin{array}{c}0.19 \mathrm{e}+01 \\
(3.29 \mathrm{e}-05) \\
(1.76 \mathrm{e}-02)\end{array}$ \\
\hline \multirow{3}{*}{ NLSE } & $\begin{array}{c}5.00 \mathrm{e}-01 \\
(1.06 \mathrm{e}-08) \\
(3.09 \mathrm{e}-04)\end{array}$ & $\begin{array}{c}2.49 \mathrm{e}+02 \\
(3.49 \mathrm{e}-03) \\
(3.20 \mathrm{e}-04)\end{array}$ & $\begin{array}{c}4.95 \mathrm{e}-01 \\
(0) \\
(0)\end{array}$ & $\begin{array}{c}4.99 \mathrm{e}-01 \\
(7.27 \mathrm{e}-12) \\
(4.53 \mathrm{e}-05)\end{array}$ & $\begin{array}{c}\mathbf{2 . 5 0 e + 0 2} \\
(8.93 \mathrm{e}-07) \\
(3.57 \mathrm{e}-05)\end{array}$ & $\begin{array}{c}5.00 \mathrm{e}-01 \\
(0) \\
(0)\end{array}$ \\
\hline & $\begin{array}{c}4.99 \mathrm{e}-01 \\
(4.01 \mathrm{e}-09) \\
(1.64 \mathrm{e}-05)\end{array}$ & $\begin{array}{c}2.50 \mathrm{e}+02 \\
(6.84 \mathrm{e}-04) \\
(1.42 \mathrm{e}-04)\end{array}$ & $\begin{array}{c}0.10 \mathrm{e}+01 \\
(0) \\
(0)\end{array}$ & $\begin{array}{c}4.99 \mathrm{e}-01 \\
(6.44 \mathrm{e}-12) \\
(5.01 \mathrm{e}-05)\end{array}$ & $\begin{array}{c}2.50 \mathrm{e}+02 \\
(9.81 \mathrm{e}-07) \\
(3.92 \mathrm{e}-05)\end{array}$ & $\begin{array}{c}9.99 \mathrm{e}-01 \\
(0) \\
(0)\end{array}$ \\
\hline & $\begin{array}{c}4.99 \mathrm{e}-01 \\
(9.08 \mathrm{e}-12) \\
(8.09 \mathrm{e}-05)\end{array}$ & $\begin{array}{c}2.50 \mathrm{e}+02 \\
(1.81 \mathrm{e}-06) \\
(7.22 \mathrm{e}-05)\end{array}$ & $\begin{array}{c}0.19 \mathrm{e}+01 \\
(0) \\
(0)\end{array}$ & $\begin{array}{c}4.99 \mathrm{e}-01 \\
(6.84 \mathrm{e}-12) \\
(5.21 \mathrm{e}-05)\end{array}$ & $\begin{array}{c}2.50 \mathrm{e}+02 \\
(9.93 \mathrm{e}-07) \\
(3.97 \mathrm{e}-05)\end{array}$ & $\begin{array}{c}0.19 \mathrm{e}+01 \\
(0) \\
(0)\end{array}$ \\
\hline \multirow{3}{*}{ WNLSE } & $\begin{array}{c}5.00 \mathrm{e}-01 \\
(1.72 \mathrm{e}-08) \\
(4.06 \mathrm{e}-04)\end{array}$ & $\begin{array}{c}2.49 \mathrm{e}+02 \\
(5.82 \mathrm{e}-03) \\
(4.55 \mathrm{e}-04)\end{array}$ & $\begin{array}{c}4.95 e-01 \\
(0) \\
(0)\end{array}$ & $\begin{array}{c}4.99 \mathrm{e}-01 \\
(2.03 \mathrm{e}-10) \\
(3.29 \mathrm{e}-05)\end{array}$ & $\begin{array}{c}\mathbf{2 . 5 0 e + 0 2} \\
(1.13 \mathrm{e}-04) \\
(3.56 \mathrm{e}-05\end{array}$ & $\begin{array}{c}5.00 \mathrm{e}-01 \\
(0) \\
(0)\end{array}$ \\
\hline & $\begin{array}{c}5.00 \mathrm{e}-01 \\
(8.41 \mathrm{e}-09) \\
(2.46 \mathrm{e}-04)\end{array}$ & $\begin{array}{c}2.49 \mathrm{e}+02 \\
(1.62 \mathrm{e}-03) \\
(2.23 \mathrm{e}-04)\end{array}$ & $\begin{array}{c}0.10 \mathrm{e}+01 \\
(0) \\
(0)\end{array}$ & $\begin{array}{c}4.99 \mathrm{e}-01 \\
(4.51 \mathrm{e}-12) \\
(4.19 \mathrm{e}-05)\end{array}$ & $\begin{array}{c}2.50 \mathrm{e}+02 \\
(9.82 \mathrm{e}-07) \\
(3.93 \mathrm{e}-05)\end{array}$ & $\begin{array}{c}0.10 \mathrm{e}+01 \\
(0) \\
(0)\end{array}$ \\
\hline & $\begin{array}{c}4.99 \mathrm{e}-01 \\
(7.17 \mathrm{e}-12) \\
(6.79 \mathrm{e}-05)\end{array}$ & $\begin{array}{c}2.50 e+02 \\
(1.61 \mathrm{e}-06) \\
(6.45 \mathrm{e}-05)\end{array}$ & $\begin{array}{c}0.19 \mathrm{e}+01 \\
(0) \\
(0)\end{array}$ & $\begin{array}{c}4.99 \mathrm{e}-01 \\
(4.70 \mathrm{e}-12) \\
(4.19 \mathrm{e}-05)\end{array}$ & $\begin{array}{c}2.50 \mathrm{e}+02 \\
(9.36 \mathrm{e}-07) \\
(3.74 \mathrm{e}-05)\end{array}$ & $\begin{array}{c}0.19 \mathrm{e}+01 \\
(0) \\
(0)\end{array}$ \\
\hline
\end{tabular}


International Journal of Software Engineering \& Applications (IJSEA), Vol.7, No.3, May 2016

Table (2.d): Scenario 4: $[\varphi=1.5, \mathrm{~N}=250$, and $\beta=0.5,1,2]$

\begin{tabular}{|c|c|c|c|c|c|c|}
\hline \multirow{3}{*}{$\begin{array}{l}\text { Method of } \\
\text { estimation }\end{array}$} & \multicolumn{6}{|c|}{$\begin{array}{c}\text { Repetition }=5000 \\
\text { True parameters: } \varphi=1.5, N=250 \text {, and } \beta=0.5,1,2 .\end{array}$} \\
\hline & \multicolumn{3}{|c|}{$\mathrm{n}=15$} & \multicolumn{3}{|c|}{$\mathrm{n}=30$} \\
\hline & $\begin{array}{c}\hat{\varphi} \\
\left(\operatorname{MSE}_{\hat{\phi}}\right) \\
\left(\operatorname{MAPE}_{\hat{\varphi}} \%\right)\end{array}$ & $\begin{array}{c}\hat{N} \\
\left(\operatorname{MSE}_{\widehat{N}_{0}}\right) \\
\left(\operatorname{MAPE}_{\hat{N}_{0}} \%\right)\end{array}$ & $\begin{array}{c}\widehat{\hat{\boldsymbol{\beta}}} \\
\left(\mathbf{M S E}_{\hat{\mathfrak{p}}}\right) \\
\left(\mathrm{MAPE}_{\hat{\beta}} \%\right)\end{array}$ & $\begin{array}{l}\quad \hat{\varphi} \\
\left(\operatorname{MSE}_{\hat{\phi}}\right) \\
\left(\operatorname{MAPE}_{\hat{\varphi}} \%\right)\end{array}$ & $\begin{array}{c}\hat{\boldsymbol{N}} \\
\left(\mathrm{MSE}_{\widehat{N}_{0}}\right) \\
\left(\mathrm{MAPE}_{\hat{N}_{0}} \%\right)\end{array}$ & $\begin{array}{c}\widehat{\hat{\boldsymbol{\beta}}} \\
\left(\mathrm{MSE}_{\tilde{\mathrm{B}}}\right) \\
\left(\mathrm{MAPE}_{\tilde{\mathbf{\beta}}} \%\right)\end{array}$ \\
\hline \multirow{3}{*}{ MILE } & $\begin{array}{c}0.14 \mathrm{e}+01 \\
(4.40 \mathrm{e}-03) \\
(5.05 \mathrm{e}-01)\end{array}$ & $\begin{array}{c}2.40 \mathrm{e}+02 \\
(8.32 \mathrm{e}+01) \\
(2.59 \mathrm{e}-01)\end{array}$ & $\begin{array}{c}4.62 \mathrm{e}-01 \\
(1.96 \mathrm{e}-04) \\
(5.31 \mathrm{e}-01)\end{array}$ & $\begin{array}{c}0.14 \mathrm{e}+01 \\
(1.19 \mathrm{e}-03) \\
(1.71 \mathrm{e}-01)\end{array}$ & $\begin{array}{c}2.39 \mathrm{e}+02 \\
(3.80 \mathrm{e}+01) \\
(1.48 \mathrm{e}-01)\end{array}$ & $\begin{array}{c}4.67 \mathrm{e}-01 \\
6.35 \mathrm{e}-05) \\
(2.26 \mathrm{e}-01)\end{array}$ \\
\hline & $\begin{array}{c}0.13 \mathrm{e}+01 \\
(7.21 \mathrm{e}-03) \\
(9.82 \mathrm{e}+01)\end{array}$ & $\begin{array}{c}2.27 \mathrm{e}+02 \\
(1.58 \mathrm{e}+02) \\
(6.02 \mathrm{e}-01)\end{array}$ & $\begin{array}{c}9.86 \mathrm{e}-01 \\
(1.99 \mathrm{e}-04) \\
(1.88 \mathrm{e}-01)\end{array}$ & $\begin{array}{c}0.13 e+01 \\
(2.38 \mathrm{e}-03) \\
(3.97 \mathrm{e}-01)\end{array}$ & $\begin{array}{c}2.24 \mathrm{e}+02 \\
(7.18 \mathrm{e}+02) \\
(3.44 \mathrm{e}-01)\end{array}$ & $\begin{array}{c}9.96 \mathrm{e}-01 \\
(3.88 \mathrm{e}-05) \\
(6.43 \mathrm{e}-02)\end{array}$ \\
\hline & $\begin{array}{c}0.14 \mathrm{e}+01 \\
(4.42 \mathrm{e}-03) \\
(5.89 \mathrm{e}-01)\end{array}$ & $\begin{array}{c}2.33 e+02 \\
(1.29 e+02) \\
(4.65 e-01)\end{array}$ & $\begin{array}{c}0.19 \mathrm{e}+01 \\
(1.59 \mathrm{e}-03) \\
(2.90 \mathrm{e}-01)\end{array}$ & $\begin{array}{c}0.14 e+01 \\
(1.29 e-03) \\
(2.15 e-01)\end{array}$ & $\begin{array}{c}2.34 \mathrm{e}+02 \\
(4.71 \mathrm{e}+01 \\
(2.17 \mathrm{e}-01\end{array}$ & $\begin{array}{c}0.19 \mathrm{e}+01 \\
(3.98 \mathrm{e}-04) \\
(1.04 \mathrm{e}-01)\end{array}$ \\
\hline \multirow{3}{*}{ NLSE } & $\begin{array}{c}0.15 e+01 \\
(1.23 e-06) \\
(8.43 e-03)\end{array}$ & $\begin{array}{c}.49 e+02 \\
(3.83 e-02) \\
(8.84 e-03)\end{array}$ & $\begin{array}{c}4.95 \mathrm{e}-01 \\
(0) \\
(0)\end{array}$ & $\begin{array}{c}0.15 e+01 \\
(2.20 e-07) \\
(1.58 e-03)\end{array}$ & $\begin{array}{c}2.49 e+02 \\
(7.31 e-03) \\
(1.69 e-03)\end{array}$ & $\begin{array}{c}.94 \mathrm{e}-01 \\
(0) \\
(0)\end{array}$ \\
\hline & $\begin{array}{c}0.15 e+01 \\
(1.55 e-07) \\
(1.29 e-03)\end{array}$ & $\begin{array}{c}2.49 e+02 \\
(4.23 e-03) \\
(1.28 e-03)\end{array}$ & $\begin{array}{c}9.99 \mathrm{e}-01 \\
(0) \\
(0)\end{array}$ & $\begin{array}{c}0.15 e+01 \\
(5.47 e-09) \\
(1.77 e-04)\end{array}$ & $\begin{array}{c}2.50 e+02 \\
(1.29 e-04) \\
(1.17 e-04)\end{array}$ & $\begin{array}{c}9.99 \mathrm{e}-01 \\
(0) \\
(0)\end{array}$ \\
\hline & $\begin{array}{c}0.15 e+01 \\
(4.31 e-07) \\
(3.09 e-03)\end{array}$ & $\begin{array}{c}2.49 e+02 \\
(1.08 e-02) \\
(2.94 e-03)\end{array}$ & $\begin{array}{c}0.20 \mathrm{e}+01 \\
(0) \\
(0)\end{array}$ & $\begin{array}{c}0.15 \mathrm{e}+01 \\
(1.27 \mathrm{e}-10) \\
(1.32 \mathrm{e}-04)\end{array}$ & $\begin{array}{c}2.50 e+02 \\
(3.09 e-06) \\
(1.24 e-04)\end{array}$ & $\begin{array}{c}0.19 \mathrm{e}+01 \\
(0) \\
(0)\end{array}$ \\
\hline \multirow{3}{*}{ WNLSE } & $\begin{array}{c}0.15 \mathrm{e}+01 \\
(1.29 \mathrm{e}-06) \\
(8.62 \mathrm{e}-03)\end{array}$ & $\begin{array}{c}2.49 \mathrm{e}+02 \\
(4.16 \mathrm{e}-02) \\
(9.27 \mathrm{e}-03)\end{array}$ & $\begin{array}{c}4.95 e-01 \\
(0) \\
(0)\end{array}$ & $\begin{array}{c}0.15 \mathrm{e}+01 \\
(2.54 \mathrm{e}-07) \\
(1.79 \mathrm{e}-03)\end{array}$ & $\begin{array}{c}2.49 \mathrm{e}+02 \\
(9.74 \mathrm{e}-03) \\
(2.06 \mathrm{e}-03)\end{array}$ & $\begin{array}{c}4.95 e-01 \mid \\
(0) \\
(0)\end{array}$ \\
\hline & $\begin{array}{c}0.15 \mathrm{e}+01 \\
(2.54 \mathrm{e}-07) \\
(1.94 \mathrm{e}-03)\end{array}$ & $\begin{array}{c}2.49 \mathrm{e}+02 \\
(7.01 \mathrm{e}-03) \\
(1.93 \mathrm{e}-03)\end{array}$ & $\begin{array}{c}9.99 \mathrm{e}-01 \\
(0) \\
(0)\end{array}$ & $\begin{array}{c}0.15 e+01 \\
(1.01 e-08) \\
(1.99 e-04)\end{array}$ & $\begin{array}{c}2.50 \mathrm{e}+02 \\
(2.65 \mathrm{e}-04) \\
(1.96 \mathrm{e}-04)\end{array}$ & $\begin{array}{c}0.10 \mathrm{e}+01 \\
(0) \\
(0)\end{array}$ \\
\hline & $\begin{array}{c}0.15 e+01 \\
(6.59 e-07) \\
(4.60 e-03)\end{array}$ & $\begin{array}{c}2.49 \mathrm{e}+02 \\
(1.69 \mathrm{e}-02) \\
(4.42 \mathrm{e}-03)\end{array}$ & $\begin{array}{c}0.20 \mathrm{e}+01 \\
(0) \\
(0)\end{array}$ & $\begin{array}{c}0.15 e+01 \\
(1.21 e-08) \\
(2.03 e-04)\end{array}$ & $\begin{array}{c}2.50 \mathrm{e}+02 \\
(2.94 \mathrm{e}-04) \\
(1.94 \mathrm{e}-04)\end{array}$ & $\begin{array}{c}0.20 \mathrm{e}+01 \\
(0) \\
(0)\end{array}$ \\
\hline
\end{tabular}


International Journal of Software Engineering \& Applications (IJSEA), Vol.7, No.3, May 2016

Table (2.d): Continued

\begin{tabular}{|c|c|c|c|c|c|c|}
\hline \multirow{3}{*}{$\begin{array}{l}\text { Method of } \\
\text { estimation }\end{array}$} & \multicolumn{6}{|c|}{$\begin{array}{c}\text { Repetition }=5000 \\
\text { True parameters: } \varphi=1.5, N=250 \text {, and } \beta=0.5,1,2 .\end{array}$} \\
\hline & \multicolumn{3}{|c|}{$\mathrm{n}=50$} & \multicolumn{3}{|c|}{$\mathrm{n}=100$} \\
\hline & $\begin{array}{l}\quad \hat{\varphi} \\
\left(\operatorname{MSE}_{\hat{\phi}}\right) \\
\left(\operatorname{MAPE}_{\hat{\varphi}} \%\right)\end{array}$ & $\begin{array}{c}\hat{\boldsymbol{N}} \\
\left(\mathrm{MSE}_{\hat{N}_{a}}\right) \\
\left(\mathrm{MAPE}_{N_{0}} \%\right)\end{array}$ & $\begin{array}{c}\widehat{\boldsymbol{\beta}} \\
\left(\mathbf{M S E}_{\tilde{\beta}}\right) \\
\left(\operatorname{MAPE}_{\hat{\beta}} \%\right)\end{array}$ & $\begin{array}{c}\hat{\hat{\varphi}} \\
\left(\operatorname{MSE}_{\hat{\hat{\varphi}}}\right) \\
\left(\operatorname{MAPE}_{\hat{\varphi}} \%\right)\end{array}$ & $\begin{array}{c}\hat{\boldsymbol{N}} \\
\left(\operatorname{MSE}_{\mathbb{N}_{n}}\right) \\
\left(\operatorname{MAPE}_{N_{0}} \%\right)\end{array}$ & $\begin{array}{c}\widehat{\boldsymbol{\beta}} \\
\left(\mathbf{M S E}_{\tilde{\tilde{\beta}}}\right) \\
\left(\operatorname{MAPE}_{\tilde{\beta}} \%\right)\end{array}$ \\
\hline \multirow{3}{*}{ MLE } & $\begin{array}{c}0.15 \mathrm{e}+01 \\
(4.65 \mathrm{e}-04) \\
(8.12 \mathrm{e}-02)\end{array}$ & $\begin{array}{c}2.41 \mathrm{e}+02 \\
(1.46 \mathrm{e}+01) \\
(7.34 \mathrm{e}-02)\end{array}$ & $\begin{array}{c}4.69 \mathrm{e}-01 \\
(2.84 \mathrm{e}-05) \\
(1.22 \mathrm{e}-01)\end{array}$ & $\begin{array}{c}0.15 \mathrm{e}+01 \\
(1.01 \mathrm{e}-04) \\
(2.72 \mathrm{e}-02)\end{array}$ & $\begin{array}{c}2.44 \mathrm{e}+02 \\
(0.27 \mathrm{e}+01) \\
(2.44 \mathrm{e}-02)\end{array}$ & $\begin{array}{c}4.73 \mathrm{e}-01 \\
(9.79 \mathrm{e}-06) \\
(5.48 \mathrm{e}-02)\end{array}$ \\
\hline & $\begin{array}{c}0.13 \mathrm{e}+01 \\
(1.16 \mathrm{e}-03) \\
(2.24 \mathrm{e}-01)\end{array}$ & $\begin{array}{c}2.27 e+02 \\
(3.12 e+01) \\
(1.87 e-01)\end{array}$ & $\begin{array}{c}0.10 \mathrm{e}+01 \\
(1.15 \mathrm{e}-05) \\
(3.01 \mathrm{e}-02)\end{array}$ & $\begin{array}{c}0.13 \mathrm{e}+01 \\
(4.73 \mathrm{e}-04) \\
(1.15 \mathrm{e}-01)\end{array}$ & $\begin{array}{c}2.35 \mathrm{e}+02 \\
(0.64 \mathrm{e}+01) \\
(5.92 \mathrm{e}-02)\end{array}$ & $\begin{array}{c}0.10 \mathrm{e}+01 \\
(1.89 \mathrm{e}-06) \\
(1.13 \mathrm{e}-02)\end{array}$ \\
\hline & $\begin{array}{c}0.14 \mathrm{e}+01 \\
(5.29 \mathrm{e}-04) \\
(1.06 \mathrm{e}-02)\end{array}$ & $\begin{array}{c}2.37 e+02 \\
(1.68 \mathrm{e}+01) \\
(1.00 \mathrm{e}-01)\end{array}$ & $\begin{array}{c}0.19 \mathrm{e}+01 \\
(1.41 \mathrm{e}-04) \\
(4.73 \mathrm{e}-02)\end{array}$ & $\begin{array}{c}0.15 \mathrm{e}+01 \\
(1.21 \mathrm{e}-04) \\
(3.65 \mathrm{e}-02)\end{array}$ & $\begin{array}{c}2.42 \mathrm{e}+02 \\
(0.30 \mathrm{e}+01) \\
(3.07 \mathrm{e}-02)\end{array}$ & $\begin{array}{c}0.19 \mathrm{e}+01 \\
(2.94 \mathrm{e}-05) \\
(1.57 \mathrm{e}-02)\end{array}$ \\
\hline \multirow{3}{*}{ NLSE } & $\begin{array}{c}0.15 \mathrm{e}+01 \\
(3.45 \mathrm{e}-08) \\
(3.06 \mathrm{e}-04)\end{array}$ & $\begin{array}{c}2.49 \mathrm{e}+02 \\
(1.20 \mathrm{e}-03) \\
(3.18 \mathrm{e}-04)\end{array}$ & $\begin{array}{c}4.96 \mathrm{e}-01 \\
(0) \\
(0)\end{array}$ & $\begin{array}{c}0.15 e+01 \\
(2.71 e-10) \\
(4.77 e-05)\end{array}$ & $\begin{array}{c}2.50 \mathrm{e}+02 \\
(5.22 \mathrm{e}-06) \\
(3.69 \mathrm{e}-05)\end{array}$ & $\begin{array}{c}5.0 \mathrm{le}-01 \\
(0) \\
(0)\end{array}$ \\
\hline & $\begin{array}{c}0.15 \mathrm{e}+01 \\
(4.89 \mathrm{e}-10) \\
(9.15 \mathrm{e}-05)\end{array}$ & $\begin{array}{l}2.50 \mathrm{e}+02 \\
(1.03 \mathrm{e}-05) \\
(8.19 \mathrm{e}-05)\end{array}$ & $\begin{array}{c}9.99 \mathrm{e}-01 \\
(0) \\
(0)\end{array}$ & $\begin{array}{c}0.15 \mathrm{e}+01 \\
(6.01 \mathrm{e}-11) \\
(5.14 \mathrm{e}-05)\end{array}$ & $\begin{array}{c}2.50 \mathrm{e}+02 \\
(9.99 \mathrm{e}-07) \\
(3.99 \mathrm{e}-05)\end{array}$ & $\begin{array}{c}9.99 \mathrm{e}-01 \\
(0) \\
(0)\end{array}$ \\
\hline & $\begin{array}{c}0.15 \mathrm{e}+01 \\
(8.83 \mathrm{e}-11) \\
(8.73 \mathrm{e}-05)\end{array}$ & $\begin{array}{c}2.50 \mathrm{e}+02 \\
(1.95 \mathrm{e}-06) \\
(7.78 \mathrm{e}-05)\end{array}$ & $\begin{array}{c}0.19 \mathrm{e}+01 \\
(0) \\
(0)\end{array}$ & $\begin{array}{c}0.15 \mathrm{e}+01 \\
(6.34 \mathrm{e}-11) \\
(5.30 \mathrm{e}-05)\end{array}$ & $\begin{array}{c}2.50 \mathrm{e}+02 \\
(9.99 \mathrm{e}-07) \\
(3.99 \mathrm{e}-05)\end{array}$ & $\begin{array}{c}0.19 \mathrm{e}+01 \\
(0) \\
(0)\end{array}$ \\
\hline \multirow{3}{*}{ WNLSE } & $\begin{array}{c}0.15 \mathrm{e}+01 \\
(3.21 \mathrm{e}-08) \\
(2.74 \mathrm{e}-04)\end{array}$ & $\begin{array}{c}2.49 \mathrm{e}+02 \\
(1.41 \mathrm{e}-03) \\
(3.25 \mathrm{e}-04)\end{array}$ & $\begin{array}{c}4.99 \mathrm{e}-01 \\
(0) \\
(0)\end{array}$ & $\begin{array}{c}0.15 \mathrm{e}+01 \\
(8.32 \mathrm{e}-10) \\
(3.39 \mathrm{e}-05)\end{array}$ & $\begin{array}{c}2.50 \mathrm{e}+02 \\
(4.22 \mathrm{e}-05) \\
(3.64 \mathrm{e}-05)\end{array}$ & $\begin{array}{c}5.00 \mathrm{e}-01 \\
(0) \\
(0)\end{array}$ \\
\hline & $\begin{array}{c}0.15 e+01 \\
(7.57 e-11) \\
(8.16 e-05)\end{array}$ & $\begin{array}{c}2.50 \mathrm{e}+02 \\
(1.99 \mathrm{e}-06) \\
(7.96 \mathrm{e}-05)\end{array}$ & $\begin{array}{c}0.10 \mathrm{e}+01 \\
(0) \\
(0)\end{array}$ & $\begin{array}{c}0.15 \mathrm{e}+01 \\
(4.13 \mathrm{e}-11) \\
(4.26 \mathrm{e}-05)\end{array}$ & $\begin{array}{c}2.50 \mathrm{e}+02 \\
(9.99 \mathrm{e}-07) \\
(3.99 \mathrm{e}-05)\end{array}$ & $\begin{array}{c}0.10 \mathrm{e}+01 \\
(0) \\
(0)\end{array}$ \\
\hline & $\begin{array}{c}0.15 e+01 \\
(7.54 e-11) \\
(7.93 e-05)\end{array}$ & $\begin{array}{c}2.50 \mathrm{e}+02 \\
(1.88 \mathrm{e}-06) \\
(7.52 \mathrm{e}-05)\end{array}$ & $\begin{array}{c}0.19 \mathrm{e}+01 \\
(0) \\
(0)\end{array}$ & $\begin{array}{c}0.15 e+01 \\
(4.56 e-11) \\
(4.47 e-05)\end{array}$ & $\begin{array}{c}2.50 \mathrm{e}+02 \\
(9.93 \mathrm{e}-07) \\
(3.97 \mathrm{e}-05)\end{array}$ & $\begin{array}{c}0.19 \mathrm{e}+01 \\
(0) \\
(0)\end{array}$ \\
\hline
\end{tabular}


International Journal of Software Engineering \& Applications (IJSEA), Vol.7, No.3, May 2016

Table 3: The MSE of six special cases of the G J-M model based on three simulated data sets.

Bold numbers indicates the best model performance.

\begin{tabular}{|c|c|c|c|c|}
\hline & Data & Data 1 & Data 2 & Data 3 \\
\hline Model & $\begin{array}{l}\text { Method of } \\
\text { estimation }\end{array}$ & & & \\
\hline Model 1 & $\begin{array}{r}\text { MIEE } \\
\text { NLSE } \\
\text { WNLSE }\end{array}$ & $\begin{array}{l}7.24 \mathrm{e}+02 \\
6.66 \mathrm{e}-03 \\
2.45 \mathrm{e}-02\end{array}$ & $\begin{array}{l}1.05 \mathrm{e}+03 \\
9.51 \mathrm{e}-04 \\
9.39 \mathrm{e}-04\end{array}$ & $\begin{array}{l}1.27 e+03 \\
8.18 e-04 \\
4.05 e-04\end{array}$ \\
\hline Model 2 & $\begin{array}{r}\text { MIEE } \\
\text { NLSE } \\
\text { WNLSE }\end{array}$ & $\begin{array}{l}2.51 \mathrm{e}+02 \\
1.58 \mathrm{e}-04 \\
2.14 \mathrm{e}-05\end{array}$ & $\begin{array}{l}5.39 \mathrm{e}+02 \\
4.68 \mathrm{e}-04 \\
1.89 \mathrm{e}-04\end{array}$ & $\begin{array}{l}8.15 \mathrm{e}+02 \\
6.89 \mathrm{e}-04 \\
6.87 \mathrm{e}-04\end{array}$ \\
\hline Model 3 & $\begin{array}{r}\text { MIEE } \\
\text { NLSE } \\
\text { WNLSE }\end{array}$ & $\begin{array}{l}8.36 \mathrm{e}+01 \\
1.20 \mathrm{e}-06 \\
4.66 \mathrm{e}-07\end{array}$ & $\begin{array}{l}2.74 \mathrm{e}+02 \\
1.23 \mathrm{e}-04 \\
2.55 \mathrm{e}-05\end{array}$ & $\begin{array}{l}5.15 \mathrm{e}+02 \\
4.89 \mathrm{e}-04 \\
2.38 \mathrm{e}-04\end{array}$ \\
\hline Model 4 & $\begin{array}{r}\text { MIEE } \\
\text { NLSE } \\
\text { WNLSE }\end{array}$ & $\begin{array}{l}2.56 \mathrm{e}+01 \\
2.69 \mathrm{e}-07 \\
5.02 \mathrm{e}-08\end{array}$ & $\begin{array}{l}1.37 \mathrm{e}+02 \\
4.27 \mathrm{e}-06 \\
1.56 \mathrm{e}-05\end{array}$ & $\begin{array}{l}3.23 \mathrm{e}+02 \\
2.79 \mathrm{e}-04 \\
1.82 \mathrm{e}-04\end{array}$ \\
\hline Model 5 & $\begin{array}{r}\text { MIEE } \\
\text { NLSE } \\
\text { WNLSE }\end{array}$ & $\begin{array}{l}0.62 \mathrm{e}+01 \\
9.01 \mathrm{e}-08 \\
1.38 \mathrm{e}-08\end{array}$ & $\begin{array}{l}6.68 \mathrm{e}+01 \\
1.13 \mathrm{e}-06 \\
3.88 \mathrm{e}-07\end{array}$ & $\begin{array}{l}2.01 \mathrm{e}+02 \\
1.14 \mathrm{e}-05 \\
2.56 \mathrm{e}-05\end{array}$ \\
\hline Model 6 & $\begin{array}{c}\text { MLE } \\
\text { NLSE } \\
\text { WNLSE }\end{array}$ & $\begin{array}{l}6.81 \mathrm{e}-01 \\
3.59 \mathrm{e}-08 \\
5.05 \mathrm{e}-09\end{array}$ & $\begin{array}{l}3.13 \mathrm{e}+01 \\
4.52 \mathrm{e}-07 \\
1.02 \mathrm{e}-07\end{array}$ & $\begin{array}{l}1.24 e+02 \\
3.75 e-06 \\
2.39 e-06\end{array}$ \\
\hline
\end{tabular}


Table 4: The RMSE of six special cases of the G J-M model based on three simulated data sets.

Bold numbers indicates the best model performance.

\begin{tabular}{|c|c|c|c|c|}
\hline & Data & Data 1 & Data 2 & Data 3 \\
\hline Model & $\begin{array}{l}\text { Method of } \\
\text { estimation }\end{array}$ & & & \\
\hline Model 1 & $\begin{array}{r}\text { MLE } \\
\text { NLSE } \\
\text { WNLSE }\end{array}$ & $\begin{array}{l}2.69 \mathrm{e}+01 \\
1.16 \mathrm{e}-02 \\
1.44 \mathrm{e}-02\end{array}$ & $\begin{array}{l}3.23 e+01 \\
8.22 e-03 \\
8.24 e-03\end{array}$ & $\begin{array}{l}3.57 e+01 \\
7.48 e-03 \\
6.59 e-03\end{array}$ \\
\hline Model 2 & $\begin{array}{r}\text { MLE } \\
\text { NLSE } \\
\text { WNLSE }\end{array}$ & $\begin{array}{l}1.58 \mathrm{e}+01 \\
4.10 \mathrm{e}-03 \\
3.55 \mathrm{e}-03\end{array}$ & $\begin{array}{l}2.32 \mathrm{e}+01 \\
6.74 \mathrm{e}-03 \\
6.46 \mathrm{e}-03\end{array}$ & $\begin{array}{l}2.85 \mathrm{e}+01 \\
7.62 \mathrm{e}-03 \\
7.39 \mathrm{e}-03\end{array}$ \\
\hline Model 3 & $\begin{array}{r}\text { MIE } \\
\text { NLSE } \\
\text { WNLSE }\end{array}$ & $\begin{array}{l}0.91 \mathrm{e}+01 \\
9.53 \mathrm{e}-04 \\
5.40 \mathrm{e}-04\end{array}$ & $\begin{array}{l}1.65 \mathrm{e}+01 \\
4.47 \mathrm{e}-03 \\
4.22 \mathrm{e}-03\end{array}$ & $\begin{array}{l}2.27 e+01 \\
6.91 e-03 \\
6.63 e-03\end{array}$ \\
\hline Model 4 & $\begin{array}{r}\text { MLE } \\
\text { NLSE } \\
\text { WNLSE }\end{array}$ & $\begin{array}{l}0.50 \mathrm{e}+01 \\
5.06 \mathrm{e}-04 \\
1.99 \mathrm{e}-04\end{array}$ & $\begin{array}{l}1.17 e+01 \\
1.72 e-03 \\
1.36 e-03\end{array}$ & $\begin{array}{l}1.80 \mathrm{e}+01 \\
5.50 \mathrm{e}-03 \\
5.61 \mathrm{e}-03\end{array}$ \\
\hline Model 5 & $\begin{array}{r}\text { MIE } \\
\text { NLSE } \\
\text { WNLSE }\end{array}$ & $\begin{array}{l}0.25 \mathrm{e}+01 \\
2.96 \mathrm{e}-04 \\
1.09 \mathrm{e}-04\end{array}$ & $\begin{array}{l}0.82 \mathrm{e}+01 \\
1.01 \mathrm{e}-03 \\
5.44 \mathrm{e}-04\end{array}$ & $\begin{array}{l}1.42 \mathrm{e}+01 \\
2.90 \mathrm{e}-03 \\
2.78 \mathrm{e}-03\end{array}$ \\
\hline Model 6 & $\begin{array}{c}\text { MLE } \\
\text { NLSE } \\
\text { WNLSE }\end{array}$ & $\begin{array}{l}7.91 \mathrm{e}-01 \\
1.87 \mathrm{e}-04 \\
6.63 \mathrm{e}-05\end{array}$ & $\begin{array}{l}0.56 \mathrm{e}+01 \\
6.59 \mathrm{e}-04 \\
2.92 \mathrm{e}-04\end{array}$ & $\begin{array}{l}1.11 e+01 \\
1.73 e-03 \\
1.26 e-03\end{array}$ \\
\hline
\end{tabular}


Table 5: The AME of six special cases of the G J-M model based on three simulated data sets.

Bold numbers indicates the best model performance.

\begin{tabular}{|c|c|c|c|c|}
\hline & Data & Data 1 & Data 2 & Data 3 \\
\hline Model & $\begin{array}{l}\text { Method of } \\
\text { estimation }\end{array}$ & & & \\
\hline Model 1 & $\begin{array}{r}\text { MLE } \\
\text { NLSE } \\
\text { WNLSE }\end{array}$ & $\begin{array}{l}2.70 \mathrm{e}+01 \\
1.17 \mathrm{e}-02 \\
1.45 \mathrm{e}-02\end{array}$ & $\begin{array}{l}3.27 e+01 \\
8.33 e-03 \\
8.35 e-03\end{array}$ & $\begin{array}{l}3.62 \mathrm{e}+01 \\
7.58 \mathrm{e}-03 \\
6.68 \mathrm{e}-03\end{array}$ \\
\hline Model 2 & $\begin{array}{r}\text { MLE } \\
\text { NLSE } \\
\text { WNLSE }\end{array}$ & $\begin{array}{l}1.54 \mathrm{e}+01 \\
4.02 \mathrm{e}-03 \\
3.48 \mathrm{e}-03\end{array}$ & $\begin{array}{l}2.32 \mathrm{e}+01 \\
6.74 \mathrm{e}-03 \\
6.48 \mathrm{e}-03\end{array}$ & $\begin{array}{l}2.88 \mathrm{e}+01 \\
7.70 \mathrm{e}-03 \\
7.47 \mathrm{e}-03\end{array}$ \\
\hline Model 3 & $\begin{array}{r}\text { MLE } \\
\text { NLSE } \\
\text { WNLSE }\end{array}$ & $\begin{array}{l}0.85 \mathrm{e}+01 \\
8.95 \mathrm{e}-04 \\
5.10 \mathrm{e}-04\end{array}$ & $\begin{array}{l}1.62 \mathrm{e}+01 \\
4.40 \mathrm{e}-03 \\
4.16 \mathrm{e}-03\end{array}$ & $\begin{array}{l}2.26 \mathrm{e}+01 \\
6.92 \mathrm{e}-03 \\
6.64 \mathrm{e}-03\end{array}$ \\
\hline Model 4 & $\begin{array}{r}\text { MLE } \\
\text { NLSE } \\
\text { WNLSE }\end{array}$ & $\begin{array}{l}0.44 \mathrm{e}+01 \\
4.48 \mathrm{e}-04 \\
1.79 \mathrm{e}-04\end{array}$ & $\begin{array}{l}1.11 \mathrm{e}+01 \\
1.66 \mathrm{e}-03 \\
1.31 \mathrm{e}-03\end{array}$ & $\begin{array}{l}1.77 e+01 \\
5.44 e-03 \\
5.55 e-03\end{array}$ \\
\hline Model 5 & $\begin{array}{r}\text { MLE } \\
\text { NLSE } \\
\text { WNLSE }\end{array}$ & $\begin{array}{l}0.20 \mathrm{e}+01 \\
2.45 \mathrm{e}-04 \\
9.14 \mathrm{e}-05\end{array}$ & $\begin{array}{l}0.75 \mathrm{e}+01 \\
9.41 \mathrm{e}-04 \\
5.08 \mathrm{e}-04\end{array}$ & $\begin{array}{l}1.37 e+01 \\
2.83 e-03 \\
2.71 e-03\end{array}$ \\
\hline Model 6 & $\begin{array}{c}\text { MLE } \\
\text { NLSE } \\
\text { WNLSE }\end{array}$ & $\begin{array}{l}6.03 e-01 \\
1.43 e-04 \\
5.16 e-05\end{array}$ & $\begin{array}{l}0.49 \mathrm{e}+01 \\
5.91 \mathrm{e}-04 \\
2.64 \mathrm{e}-04\end{array}$ & $\begin{array}{l}1.05 e+01 \\
1.66 e-03 \\
1.21 e-03\end{array}$ \\
\hline
\end{tabular}

\section{CONCUlding REMARKS}

The GJ-M model is a general formula of the very well-known Jelinski-Moranda model (1972).This general formula can introduce different failure rate behavior sub-models to help suit more different situations. In this paper, we have explored the performance of three method of estimation for the GJ-M model through simulating many failure system scenarios. Furthermore, we have investigated the performance of some of the sub-models as special cases of the GJ-M model.We have made some conclusions and recommendations based on our simulation results:

- The NLSE and WNLSE methods perform well, both of them give efficient and accurate estimates in all our studied cases and we also see that they do better than the MLE method. 
- Because selecting appropriate weighting function is acrucial concern of the WNLSE method it has value to try more weight functions either optimal or empirical for more enhancement of the performance of the WNLSE method.

- Generating several sub-models of the GJ-M model increases the possibility of finding the best fit model that suit several situations.

- It is worth to consider the WNLSE method with the reliability models considering that they have non-constant variance with testing time.

\section{REFERENCES}

[1] Chai, T., and Draxler, R. ,Root mean square error (RMSE) or mean absolute error (MAE)? Arguments against avoiding RMSE in the literature, Geoscientific Model Development. 7, 12471250. doi:10.5194/gmd-7-1247-2014.

[2] Gentry,Travis W., Bogdan M. Wilamowski, and Larry R. Weatherford, "A Comparison of Traditional Forecasting Techniques and Neural Networks", presented at ANNIE'95 - Artificial Neural Networks in Engineering, St. Louis, Missouri, USA, November 12-15, 1995; also in Intelligent Engineering Systems Through Artificial Neural Networks vol 5, pp. 765-760, ed. C. H. Dagli, M. Akay, C. L. P Chen, B. R. Fernandez, J. Gosh, ASME PRESS, New York 1995.

[3] Jelinski Z. and Moranda P. B. , Software reliability research, Statistical computer performance evaluation (Edited by W. Freiberger), Academic Press, New York,(1972), pp. 465-497.

[4] Liu J., Liu Y., Xu M., Parameter Estimation of Jelinski-Moranda Model Based on Weighted Nonlinear Least Squares and Heteroscedasticity, arXiv preprint arXiv:1503.00094, 2015, pp.1-17

[5] Lutfiah Ismail Al turk andEftekhar Gabel Alsolami, Jelinski-Moranda, Software Reliability Growth Model: A Brief Literature and Modification, International Journal of Software Engineering and Applications (IJSEA), Vol.7, No.2, March 2016, pp.33-44.

[6] Zhang, X., Teng, X. and Pham, H., Considering Fault Removal Efficiency in Software Reliability Assessment, IEEE Transactions on Systems, Man and Cybernetics-part A, Vol.33, No.1, 2003; 114120.

\section{AUTHOR}

Lutfiah Ismail Al turkis currently working as Associate Professor of Mathematical Statistics in Statistics Department at Faculty of Sciences, King AbdulAziz University, Saudi Arabia. Lutfiah Ismail Al turk obtained her B.Sc degree in Statistics and Computer Science from Faculty of Sciences, King AbdulAziz University in 1993 and M.Sc (Mathematical statistics) degree from Statistics Department, Faculty of Sciences, King AbdulAziz University in 1999. She received her Ph.D in Mathematical Statistics from university of Surrey, UK in 2007. Her current research interests include Software reliability modeling and Statistical Machine Learning.

Eftekhar Gabel Alsolami is presently Teaching Assistant in Mathematics Department at Faculty of Sciences, University of Jeddah, Saudi Arabia. Eftekhar Gabel Alsolami obtained her B.Sc degree in Statistics from Faculty of Sciences, King AbdulAziz University in 2011. 